\title{
First Amendment Protection for Commercial Advertising: The New Constitutional Doctrine
}

Governmental regulation of commercial advertising has become a major focus of challenges to established first amendment doctrine. ${ }^{1}$ An increasing number of suits have raised constitutional objections to regulations of false or deceptive advertising, ${ }^{2}$ regulations of offensive advertising, ${ }^{3}$ prohibitions of commercial advertising in certain forums, ${ }^{4}$ prohibitions of price advertising for particular products or services, ${ }^{5}$ and prohibitions of all advertising for particular products or services. ${ }^{6}$ Until recently, the majority of courts upheld such regulations under the Supreme Court's ruling in Valentine $v$. Chrestensen ${ }^{7}$ that "purely commercial advertising" is unprotected by the first amendment. ${ }^{8}$

In the last two years the Court has subjected the Chrestensen doctrine to intensive scrutiny. In Bigelow v. Virginia, ${ }^{9}$ decided in

' Commercial advertising, or "commercial speech," cases have recently been prominent in the Supreme Court's docket. See Virginia State Bd. of Pharmacy v. Virginia Citizens Consumer Council, 96 S. Ct. 1817 (1976); Bigelow v. Virginia, 421 U.S. 809 (1975); Linmark Assocs., Inc. v. Township of Willingboro, 535 F.2d 786 (3d Cir. 1976), cert. granted, 45 U.S.L.W. 3340 (U.S. Nov. 9, 1976); Population Servs. Int'l v. Wilson, 398 F. Supp. 321 (S.D.N.Y. 1975), prob. juris. noted, 96 S. Ct. 2621 (1976); Bates v. State Bar of Arizona, 555 P.2d 640 (Ariz.), prob. juris. noted, 97 S. Ct. 53 (1976). Before 1975, the full Court gave extended consideration to the constitutional status of commercial advertising in only two cases, Pittsburgh Press Co. v. Pittsburgh Comm'n on Human Relations, 413 U.S. 376 (1973), and Valentine v. Chrestensen, 316 U.S. 52 (1942).

${ }^{2}$ See, e.g., Beneficial Corp. v. FTC, 542 F.2d 611 (3d Cir. 1976); FTC v. National Comm'n on Egg Nutrition, 517 F.2d 485, 489 (7th Cir. 1975), cert. denied, 96 S. Ct. 2451 (1976).

${ }^{3}$ See, e.g., State v. Cardwell, 539 P.2d 169 (Or. App. 1975).

4 See, e.g., Howard v. State Dep't of Highways, 478 F.2d 581 (10th Cir. 1973) (regulation of placement of commercial billboards).

5 See, e.g., Virginia State Bd. of Pharmacy v. Virginia Citizens Consumer Council, 96 S. Ct. 1817 (1976) (prescription drug price advertising); Terminal-Hudson Elecs., Inc. v. Department of Consumer Affairs, 407 F. Supp. 1075 (C.D. Cal. 1976), vacated, 96 S. Ct. 2619 (1976), (advertising prices and places to purchase corrective eyeglasses).

'See, e.g., Bigelow v. Virginia, 421 U.S. 809 (1975) (abortion advertisements); Pittsburgh Press Co. v. Pittsburgh Comm'n on Human Relations, 413 U.S. 376 (1973) (sexually discriminatory employment proposals).

7316 U.S. 52 (1942).

${ }^{8}$ Id. at 54; see New York Times Co. v. Sullivan, 376 U.S. 254, 266 (1964) (distinguishing protected editorial advertisements from "purely commercial" advertisements); Breard v. Alexandria, 341 U.S. 622, 642 (1951); Martin v. City of Struthers, 319 U.S. 141, 142 n.1 (1943); cf. Lehman v. City of Shaker Heights, 418 U.S. 298 (1974) (local government regulation permitting only commercial advertising on public transit system does not create a "public forum" for the purpose of political advertising).

421 U.S. 809 (1975). 
1975, the Court described Chrestensen as "distinctly a limited" decision ${ }^{10}$ and announced that the constitutionality of the regulation of commercial advertising was to be assessed by "weighing the First Amendment interest against the governmental interest alleged." One year later, in Virginia State Board of Pharmacy $v$. Virginia Citizens Consumer Council, ${ }^{12}$ the Court squarely rejected the "simplistic approach" of Chrestensen ${ }^{13}$ and held that even purely commercial advertising is not "wholly outside the protection of the First Amendment." 14

Bigelow and Virginia Board of Pharmacy cast serious doubt on the constitutionality of the different forms of state action that restrict business advertising. However, the Court's rulings may be difficult for lower courts to apply consistently. Neither Bigelow nor Virginia Board of Pharmacy defines commercial speech, and only in Virginia Board of Pharmacy does the Court begin tentatively to formulate the criteria courts should take into account in balancing the rights of businesses and consumers against the regulatory interests of the government. Both a definition and a conception of the relevant criteria must be developed if lower courts, agencies, and advertisers are to have adequate guidelines for assessing the constitutionality of advertising regulations.

This comment will examine the constitutional status of commercial advertising before and after Bigelow and Virginia Board of Pharmacy, and will argue that a distinction between commercial and noncommercial speech remains valid. ${ }^{15}$ The comment will then

1" Id. at 819. The Court described the decision in Chrestensen as only upholding a "reasonable regulation of the manner in which commercial advertising could be distributed," adding:

The fact that it had the effect of banning a particular handbill does not mean that Chrestensen is authority for the proposition that all statutes regulating commercial advertising are immune from constitutional challenge. The case obviously does not support any sweeping proposition that advertising is unprotected per se.

Id. at $819-20$.

"Id. at 826 .

1296 S. Ct. 1817 (1976).

${ }^{13}$ Id. at $1824-25$.

"Id. at 1825 .

15. This comment is primarily concerned with the status of advertising under the first amendment. Related issues, such as the first amendment implications of governmental regulation of securities sales and promotion, see, e.g., SEC v. Texas Gulf Sulphur Co., 446 F.2d 1301, 1305-06 (2d Cir.), cert. denied, 404 U.S. 1005 (1971); the first amendment standard applicable in assessing governmental regulation of speech related to antitrust violations or unfair trade practices, see, e.g., Holiday Magic, Inc. v. Warren, 357 F. Supp. 20 (E.D. Wis. 1973), vacated, 497 F.2d 687 (7th Cir. 1974); the first amendment status of business credit reports, see, e.g., Wortham v. Dun \& Bradstreet, Inc., 399 F. Supp. 633 (S.D. Tex. 1975); or the first amendment protection of credit reports on private individuals, see, e.g., Millstone 
analyze the difficulties of defining commercial speech and advocate that courts adopt a definition based on the lower first amendment value the Supreme Court has found in commercial speech. Finally, the comment will examine some of the criteria courts should consider in reviewing four illustrative types of regulations of commercial advertising.

\section{The Commercial Speech Doctrine and the Impact of Bigelow and Virginia Board of Pharmacy}

\section{A. The "Two-Level" Theory: Commercial Speech as Wholly Unprotected}

The principle that commercial advertising is unprotected by the first amendment was first enunciated in Valentine $v$. Chrestensen, ${ }^{16}$ where the Supreme Court upheld an ordinance prohibiting the distribution of handbills containing "commercial and business advertising matter." 17 One side of Chrestensen's handbill advertised a commercial display of a submarine. The reverse side contained a protest against the action of New York City officials denying the submarine wharfage facilities. In an opinion later characterized as "casual, almost offhand," 18 the Court noted that the first amendment protects leafleting for the purpose of communicating information and disseminating opinion on issues of public importance, ${ }^{19}$ but held that "[w]e are equally clear that the Constitution imposes no such restraint on government as respects purely commercial advertising." ${ }^{20}$ The Court dismissed the presence of the protest against the city officials, finding that it had been added to the handbill "with the intent, and for the purpose, of evading the prohibition of the ordinance." 21

This ruling was consistent with previous Supreme Court deci-

v. O'Hanlon Reports, Inc., 528 F.2d 829 (8th Cir. 1976), are considered only incidentally. Most factors relevant to the first amendment status of business advertising, however, also apply in these other contexts.

17316 U.S. 52 (1942). For a fuller treatment of the background of the commercial speech doctrine, see Devore \& Nelson, Commercial Speech and Paid Access to the Press, 26 Hastings L.J. 745, 747-64 (1975); Redish, The First Amendment in the Market Place: Commercial Speech and the Values of Free Expression, 39 GEo. WASH. L. REv. 429, 448-72 (1971).

17316 U.S. at 53. In Schneider v. State, 308 U.S. 147 (1939), the Court had ruled that local ordinances forbidding all forms of leafleting were unconstitutional. The New York City ordinance at issue in Chrestensen had been amended to apply only to "commercial and business advertising matter" in 1938.

${ }^{18}$ Cammarano v. United States, 358 U.S. 498, 514 (1959) (Douglas, J., concurring).

19316 U.S. at 54.

211 Id.

${ }^{21}$ Id. at 55 . 
sions concerning advertising regulations, ${ }^{22}$ and subsequent opinions were similarly unconcerned with the first amendment implications of advertising restrictions. ${ }^{23}$ These cases treated business advertising as merely a form of economic activity subject to government regulation within the less stringent limits of due process. ${ }^{24}$ Chrestensen's significance lay in making explicit the assumed irrelevance of the first amendment and in suggesting the "primary purpose" definition of unprotected commercial speech. ${ }^{25}$ Under this approach, if a communication is primarily intended to generate business profits, it can be regulated as a form of economic activity and enjoys no first amendment protection; but if the primary purpose is to convey information or views on public issues, the communication is accorded the full protection of the first amendment. ${ }^{26}$ So formulated, the Chrestensen doctrine constitutes a branch of the "two-level" theory of the first amendment, ${ }^{27}$ which classifies speech

${ }^{22}$ See, e.g., Semler v. Oregon State Bd. of Dental Examiners, 294 U.S. 608 (1935) (prohibition of advertising by dentists); Packer Corp. v. Utah, 285 U.S. 105 (1932) (prohibition of cigarette advertising on billboards).

${ }^{23}$ See, e.g., Head v. New Mexico Bd. of Examiners in Optometry, 374 U.S. 424 (1963) (prohibition of optical advertising); Williamson v. Lee Optical, Inc., 348 U.S. 483 (1955) (same); Railway Express Agency v. New York, 336 U.S. 106 (1949) (prohibition of vehicular advertising unrelated to owner's business). These cases upheld advertising regulations under a standard requiring only a "rational connection between the remedy provided and the evil to be curbed." Thomas v. Collins, 323 U.S. 516, 530 (1945). When first amendment rights are recognized to exist, the Court accords them a "preferred position," $i d$., and requires a demonstration of an "important," "significant," or "compelling" governmental interest to justify infringements. See, e.g., Erznoznik v. City of Jacksonville, 422 U.S. 205, 217 (1975); Grayned v. City of Rockford, 408 U.S. 104, 115 (1972); NAACP v. Button, 371 U.S. 415, 438 (1963).

${ }^{24}$ The Court's attitude in these decisions is aptly captured by a remark in Emerson, Toward a General Theory of the First Amendment, 72 YALE L.J. 877, 949 n.93 (1963): "Communications in connection with commercial transactions generally relate to a separate sector of social activity involving the system of property rights rather than free expression."

${ }^{25}$ Compare Valentine v. Chrestensen, 316 U.S. 52, 55 (1942), with Jamison v. Texas, 318 U.S. 413,416 (1943).

25 See Redish, The First Amendment in the Marketplace: Commercial Speech and the Values of Free Expression, 39 Geo. WASH. L. REv. 429, $451-58$ (1971); Developments in the Law-Deceptive Advertising, 80 Harv. L. Rev. 1005, 1028 (1967); 23 DePaul L. Rev. 1258, 1262 (1974).

The term "full protection" as used in this comment refers to the degree of protection that would be accorded to noncommercial speech in any particular regulatory context. For example, when fully protected speech is subject to a prior restraint, the government "carries a heavy burden of showing justification for the imposition of such a restraint." Nebraska Press Ass'n v. Stuart, 96 S. Ct. 2791, 2802 (1976). When fully protected speech constitutes advocacy of unlawful conduct it can be punished only if the advocacy "is directed to inciting or producing imminent lawless action and is likely to incite or produce such action." Brandenburg v. Ohio, 395 U.S. 444, 447 (1969).

${ }^{27}$ See Karst, Equality as a Central Principle in the First Amendment, 43 U. CHI. L. Rev. 20, 33 (1975). The term "two-level theory" was coined by Professor Harry Kalven, Jr. See H. 
as either fully protected or wholly unprotected..$^{28}$

The primary purpose definition of unprotected commercial speech was eventually rejected as the Court recognized that the motives or objectives of the speaker bear no necessary relationship to the value of his expression. ${ }^{29}$ The test was formally denounced in New York Times Co. $v$. Sullivan, ${ }^{30}$ the landmark decision creating a conditional first amendment defense against defamation actions by public officials. The libel alleged in the suit had appeared in a newspaper advertisement soliciting funds for the civil rights movement. The Court, noting that the profit motive of an author or newspaper publisher has no first amendment significance, ${ }^{31}$ found it immaterial that the Times had been paid to print the advertisement. In place of the primary purpose definition, the Court announced a new variant of the two-level theory. Chrestensen was distinguished on the ground that "[ $t]$ he publication here was not a 'commercial advertisement'" but instead "communicated information, expressed opinion, recited grievances, protested claimed abuses, and sought financial support on behalf of a movement whose existence and objectives are matters of the highest public interest and concern." 32 By drawing a line between "purely commercial" and "editorial" advertising, ${ }^{33}$ the Court keyed the defini-

Kalven, The Negro and the First Amendment 45-46 (1966); Kalven, The Metaphysics of the Law of Obscenity, 1960 Sup. CT. Rev. 1, 10-12.

2* The classic statement is in Chaplinsky v. New Hampshire, 315 U.S. 568, $571-72$ (1942):

There are certain well-defined and narrowly limited classes of speech, the prevention and punishment of which have never been thought to raise any Constitutional problem. These include the lewd and obscene, the profane, the libelous, and the insulting or "fighting" words-those which by their very utterance inflict injury or tend to incite an immediate breach of the peace. It has been well observed that such utterances are no essential part of any exposition of ideas, and are of such slight social value as a step to truth that any benefit that may be derived from them is clearly outweighed by the social interest in order and morality.

See Roth v. United States, 354 U.S. 476 (1957) (obscenity has no "socially redeeming value"); Beauharnais v. Illinois, 343 U.S. 250 (1952) (libel is unprotected speech). The Court continues to refer to narrow classes of unprotected speech in its opinions. See, e.g., Bigelow v. Virginia, 421 U.S. 809, 819 (1975) (listing fighting words, obscenity, libel, and incitement). For a discussion of the role of categorization in first amendment analysis, see Ely, Flag Desecration: A Case Study in the Roles of Categorization and Balancing in First Amendment Analysis, 88 HaRv. L. REv. 1482 (1975).

${ }^{29}$ New York Times Co. v. Sullivan, 376 U.S. 254, 266 (1964); see Ginzburg v. United States, 383 U.S. 463, 474 (1966); Smith v. California, 361 U.S. 147, 150 (1959).

${ }^{30} 376$ U.S. 254 (1964).

"Id. at 266, citing Smith v. California, 361 U.S. 147, 150 (1959), where the Court had noted that "[i]t is of course no matter" that the dissemination of books and other forms of literature "takes place under commercial auspices."

32376 U.S. at 266.

${ }^{33}$ The Court noted that "any other conclusion would discourage newspapers from carry- 
tion of commerical speech to the content of the speech rather than the purpose of the advertiser; speech containing information and opinion on matters of "highest public interest and concern" is fully protected, even when it appears in the form of paid advertising. The Court left unquestioned, however, Chrestensen's basic tenet that "purely commercial advertising" is wholly unprotected by the first amendment. ${ }^{34}$

\section{B. The Pittsburgh Press Decision: An Intimation of Some Protection for Commercial Speech}

In Pittsburgh Press Co. v. Pittsburgh Commission on Human Relations, ${ }^{35}$ the Supreme Court reexamined the constitutional status of commercial advertising. Construing a local ordinance that prohibited employment discrimination on the basis of sex ${ }^{36}$ the Pittsburgh Commission on Human Relations ruled that it was discriminatory for employers to publish job advertisements under newspaper columns designated by sex..$^{37}$ The Commission found that the Pittsburgh Press had violated a separate aider and abettor section of the ordinance by agreeing to print employment want ads under such columns, and enjoined the newspaper's use of columns classified by sex. On appeal, the injunction was affirmed, ${ }^{38}$ but narrowed to allow the publication of advertisements under sex-

ing 'editorial advertisements' of this type, and so might shut off an important outlet for the promulgation of information and ideas by persons who do not themselves have access to publishing facilities...."Id.

34 See 23 DePaul L. Rev. 1258, 1267 (1974).

35413 U.S. 376 (1973).

36 Pittsburgh, Pa., Ordinance 75 (Feb. 28, 1967), as amended, Ordinance 395 (July 7, 1969). As excerpted by the Court, the relevant provisions of the ordinance made it an unlawful employment practice

(a) For any employer to refuse to hire any person or otherwise discriminate against any person with respect to hiring . . . because of . . . sex. . . .

(e) For any "employer," employment agency or labor organization to publish or circulate, or to cause to be published or circulated, any notice or advertisement relating to "employment" or membership which indicates any discrimination because of . . . sex.

(j) For any person, whether or not an employer, employment agency or labor organization, to aid . . . in the doing of any act declared to be an unlawful employment practice by this ordinance....

Id. at 378 .

${ }^{37}$ Petition for Certiorari at 1a-18a, Pittsburgh Press Co. v. Pittsburgh Comm'n on Human Relations, 413 U.S. 376 (1973).

38 Pittsburgh Press Co. v. Pittsburgh Comm'n on Human Relations, $4 \mathrm{~Pa}$. Commw. Ct. 448, 287 A.2d 161 (1972). 
designated columns for positions exempt from the ordinance. ${ }^{39} \mathrm{~A}$ divided Supreme Court ${ }^{40}$ affirmed.

Justice Powell's majority opinion addressed two issues central to the commercial speech doctrine: whether the newspaper's publication of want ads under particular column headings was commercial speech, and if it was, how it should be treated under the first amendment. ${ }^{41}$ The Court first established that the want ads were themselves commercial speech. ${ }^{42}$ The majority reaffirmed that the content of speech rather than the advertiser's profit motive is determinative of whether speech is commercial..$^{43}$ Comparing the content of the want ads with the handbill in Chrestensen and the editorial advertisement in New York Times, the Court concluded that the want ads were closer to the handbill. ${ }^{44}$ "The critical feature of the advertisement in Valentine $v$. Chrestensen was that, in the Court's view, it did no more than propose a commercial transaction, the sale of admission to a submarine." 45 Since the want ads were "no more than a proposal of possible employment," they were "classic examples of commercial speech." 46

The Court's characterization of commercial speech as speech that does "no more than propose a commercial transaction" was probably intended not as an exclusive definition but only as a description of a prototypical form. ${ }^{47}$ The Pittsburgh Press had not

${ }^{39}$ Id. at $470,287 \mathrm{~A} .2 \mathrm{~d}$ at 172 .

1" Justice Powell's majority opinion was joined by Justices Brennan, White, Marshall and Rehnquist; Chief Justice Burger and Justices Douglas, Stewart, and Blackmun each filed dissents.

"The Court also had to resolve contentions that the advertising restriction unconstitutionally impaired the newpaper's institutional viability by depriving it of a source of revenue, 413 U.S. at $382-83$, and that the injunction was an impermissible prior restraint. Id. at 389 90. The majority rejected the first argument since the record here, unlike that in Grosjean v. American Press Co., 297 U.S. 233 (1936) (where the Court invalidated a law taxing the advertising revenue of newspapers with circulations over 20,000), failed to show "any purpose of muzzling or curbing the press" or any significant financial consequences to the newspaper. 413 U.S.at 383. See United States v. Hunter, 459 F.2d 205, 212 (4th Cir.), cert. denied, 409 U.S. 934 (1972). See also De Vore \& Nelson, Commercial Speech and Paid Access to the Press, 26 Hastings L.J. 745, 772-74 (1975). The second contention was rejected because the order was "based on a continuous course of repetitive conduct," was clear, and did not sweep more broadly than necessary, 413 U.S. at 390 .

12413 U.S. at $384-85$.

43 Id. at 385 .

"Id.

45 Id.

18 Id.

${ }^{17}$ In subsequent commercial speech decisions, the Court has adopted this characterization as the paradigm case of commecial speech. See Virginia State Bd. of Pharmacy v. Virginia Citizens Consumer Council, 96 S. Ct. 1817, 1826, 1830 n.24 (1976); Bigelow v. Virginia, 421 U.S. 809, 821 (1975). 
proposed a commercial transaction, but had published the employment proposals of other businesses for a fee. The newspaper contended that since it had only exercised its editorial judgment in accepting and arranging the want ads, it had not engaged in commercial speech. With little discussion or apparent difficulty, the Court concluded that the media may be engaging in commercial speech when they accept advertisements that do no more than propose a transaction. ${ }^{48}$ Here the offending speech involved the arrangement of facially neutral want ads, rather than the acceptance of discriminatory advertisements..$^{49}$ Nevertheless, Justice Powell found that the close relationship between the information in the column headings and the proposals of employment made the column designations and want ads "an integrated commercial statement" conveying "essentially the same message as an overtly discriminatory want ad." 50 The newspaper's editorial judgment in providing column headings, as well as its decision to accept the advertisements, was expression within the category of commercial speech. The Court's decision leaves the definition of commercial speech unclear. The prototypical case is speech that does no more than propose a commercial transaction; but the distribution of such speech by the media, and in some circumstances, the distribution of commercial proposals under particular editorial formats, will be considered commercial speech as well. ${ }^{51}$

48 The Court relied in particular on New York Times Co. v. Sullivan, 376 U.S. 254 (1964), which it read as establishing that a newspaper publishing a falsely defamatory advertisement with knowledge of or reckless disregard for its falsity could be punished for libel. The Court also noted that in Capitol Broadcasting Co. v. Mitchell, 333 F. Supp. 582 (D.D.C. 1971), aff'd, 405 U.S. 1000 (1972), cigarette commercials were treated as commercial speech even though the first amendment attack on the proscription of television and radio cigarette advertising had been brought by broadcasters rather than cigarette manufacturers. 413 U.S. at 386; see United States v. Hunter, 459 F.2d 205 (4th Cir.), cert. denied, 409 U.S. 934 (1972). But cf. Bigelow v. Virginia, 421 U.S. 809, 828 (1975) (application of advertising prohibition to publisher and editor of newspaper rather than advertiser "incurred more serious First Amendment overtones").

" Since no preferences for men or women applicants were indicated in the employment want ads themselves, only their placement under sex-designated column headings made them even implicitly discriminatory. See 413 U.S. at $387-88$.

${ }^{50}$ Id. at 388 .

${ }^{51}$ The dissenters were disturbed by what they perceived as an expansion of the commercial speech doctrine, fearing that the majority's authorization of governmental control over the newspaper's advertising layout might portend approval of governmental interference with other aspects of a newspaper's composition. Id. at 393 (Burger, C.J., dissenting); id. at 403 (Stewart, J., dissenting); see The Supreme Court, 1972 Term, 87 Harv. L. Rev. 55, 157 (1973). The majority emphatically denied this interpretation, stating that nothing in the Court's decision would "authorize any restriction . . . on stories or commentary originated by Pittsburgh Press, its columnists, or its contributors." Justice Powell unequivocally reaffirmed "the 
Having determined that the Pittsburgh Press had engaged in commercial speech, the Court addressed the first amendment status of commercial speech in response to the newspaper's argument that the Chrestensen doctrine that commercial speech is wholly unprotected should be overruled. ${ }^{52}$ Justice Powell's guarded answer was that "[w]hatever the merits of this contention may be in other contexts," it could not be accepted in a case in which the advertised commercial activity was illegal. ${ }^{53}$ The Court suggested that regulations of advertising for legitimate commercial activity should be assessed by balancing "[a]ny First Amendment interest which might be served by an ordinary commercial proposal" against "the governmental interest supporting the regulation." ${ }_{54}$ Although this statement is dictum and somewhat cryptic, it clearly implies a rejection of the view that commercial speech is per se unprotected. In place of the simplistic two-level theory, the Court suggested a more sophisticated approach: first, a court should determine whether a particular advertisement is within the definition of commercial speech; ${ }^{55}$ and second, if it is commercial speech, the court should assess whether the governmental interest behind the regulation outweighs the first amendment value of the speech. For the first time the Court implied that speech that does "no more than propose a commercial transaction" is not wholly unprotected by the first amendment.

C. The Impact of Bigelow and Virginia Board of Pharmacy: The Demise of the Two-Level Theory

Two years after Pittsburgh Press, the Supreme Court reconsidered the constitutional status of commercial advertising. In

protection afforded to editorial judgment and to the free expression of views on these and other issues, however controversial." 413 U.S. at 391.

The dissenters were also disturbed because the newspaper's column headings were far removed from speech that could be characterized as criminal incitement. See id. at $395 \mathrm{n} .2$ (Burger, J., dissenting) (case does not present "a blatant involvement by a newspaper in a criminal transaction"); id. at 398 (Douglas, J., dissenting) (speech here not "closely brigaded" with prohibited action); 48 TUL. L. REv. 426, $429 \&$ n.14 (1974).

${ }_{52} 413$ U.S. at 388.

${ }^{53}$ Id.

${ }^{54}$ The Court's full statement was: "Any First Amendment interest which might be served by advertising an ordinary commercial proposal and which might arguably outweigh the governmental interest supporting the regulation is altogether absent when the commercial activity itself is illegal and the restriction on advertising is incidental to a valid limitation on economic activity." Id. at 389.

55413 U.S. at 382. 
Bigelow $v$. Virginia ${ }^{56}$ the Court overturned the conviction of a Virginia newspaper editor who had violated a Virginia statute ${ }^{57}$ by publishing an advertisement for an abortion referral agency in New York. The Court's decision drew on a number of factors, none of which appears determinative. Although the advertisement had been published before the Court recognized a constitutional right to abortion, ${ }^{58}$ the ad's message took on added significance since it "pertained to constitutional interests." 59 The advertisement not only proposed a commercial transaction, but also contained "factual material of clear 'public interest" "' the ad greater first amendment value in the eyes of the Court. The Court also emphasized that the advertising Virginia sought to suppress was for a service provided in New York, noting that Virginia's police powers could not control abortions performed in New York, ${ }^{61}$ that Virginia could not prevent its citizens from traveling to New York to obtain an abortion, ${ }^{62}$ and that Virginia's regulation would

s6 421 U.S. 809 (1975). The Court divided 7 to 2, with Justices Rehnquist and White dissenting.

${ }^{57}$ "If any person, by publication, lecture, advertisement, or by the sale or circulation of any publication, or in any manner, encourage or prompt the procuring of abortion or miscarriage, he shall be guilty of a misdemeanor." VA. CoDE $\$ 18.1-63$ (1960).

${ }^{58}$ Roe v. Wade, 410 U.S. 113 (1973); Doe v. Bolton, 410 U.S. 179 (1973). The Court initially vacated and remanded Bigelow's conviction for further consideration in light of the abortion cases. 413 U.S. at 909 . On remand, the Virginia Supreme Court reaffirmed the judgment, Bigelow v. Commonwealth, 214 Va. 341, 342, 200 S.E.2d 680 (1973). The Court took the case again and agreed with the state that " 'this is a First Amendment case' and 'not an abortion case.'” Bigelow v. Virginia, 421 U.S. 809, 815 n.5 (1975).

${ }^{59} 421$ U.S. at 822.

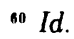

B1 421 U.S. at $823,824,827,828$. At one point the Court seemed to announce a per se rule prohibiting the regulation of advertising for out-of-state commercial activity, at least when that activity is legal; id. at 824-25; see id. at 835-36 (Rehnquist, J., dissenting). Such a ruling would conflict with prior decisions, see, e.g., Head v. New Mexico Bd. of Examiners in Optometry, 374 U.S. 424 (1963) (New Mexico newspaper and radio station enjoined from publishing advertisements for Texas optometrist in violation of New Mexico law); Delamater v. South Dakota, 205 U.S. 93, 104 (1907) (upholding "the authority of the States to forbid agents of non-resident liquor dealers from coming within their borders to solicit contracts for the purchase of intoxicating liquors which otherwise the citizen of the State 'would not have thought of making' "). There is no indication the Court intended to overrule these cases. See 421 U.S. at 825 n.10 (preserving the result in Head).

The majority's minimization of Virginia's interests in regulating advertising for out-ofstate transactions is more appropriate for personal services performed out-of-state, such as abortions, than for sales of products that could be purchased out-of-state and brought into Virginia in violation of Virginia law. For example, if Virginia prohibited the possession of handguns, and Virginia newspapers carried advertisements for the lawful sale of handguns in New York, a court might reasonably find that the advertisements sufficiently threatened the enforcement of Virginia's law to warrant their suppression.

${ }^{62} 421$ U.S. at 824, 827; see, e.g., Shapiro v. Thompson, 394 U.S. 618, 629-31 (1969); United States v. Guest, 383 U.S. 745, 757-59 (1966). 
burden interstate commerce in periodicals or newspapers carrying such advertisements. ${ }^{63}$ Pittsburgh Press did not legitimize the regulation, since the abortion service advertised, unlike employment discrimination, was legal in New York at the time the ad was published. ${ }^{64}$ The Court applied a standard requiring the government to demonstrate that the legitimate public interests in regulation outweigh the value of the speech. ${ }^{65}$

Although the state asserted interests in shielding women from "commercial pressure" to obtain an abortion" and in protecting women in Virginia from unscrupulous practitioners in New York, ${ }^{67}$ the Court struck down the advertising regulation as applied to Bigelow. The connection between abortions performed in New York and Virginia's internal police powers was too tenuous to justify the prohibition. ${ }^{68}$ However, Justice Blackmun was careful to reserve determination of "the precise extent to which the First Amendment permits regulation of advertising that is related to activities the State may legitimately regulate or even prohibit." ${ }^{69}$

Less than one year later, the Court had an opportunity to rule on the constitutional status of advertising for a type of activity within the state's police powers. In Virginia State Board of Phar-

${ }^{93} 421$ U.S. at 828-29. The Court noted that similiar abortion referral advertisements had appeared in Redbook magazine, a national publication. Id. at 814 .

at Id. at $821,822-23$.

.5 421 U.S. at 826; see text and notes at notes 172-73 infra.

ss See Bigelow v. Commonwealth, 213 Va. 191, 196, 191 S.E.2d 173, 176 (1972):

It is clearly within the police power of the state to enact reasonable measures to ensure that pregnant women in Virginia who decide to have abortions come to their decisions without the commercial advertising pressure usually incidental to the sale of a box of soap powder.

67 Id.

ax 421 U.S. at $827-28$. The actual grounds for the decision are difficult to determine because the Court did not clearly distinguish between such factors as the limits of Virginia's police power, the legality of the transaction, the impediment to the right to travel, and the possible burden on interstate commerce. See The Supreme Court, 1974 Term, 89 Harv. L. REv. 47, 118 n.51 (1975).

"4 421 U.S. at 825 ; see id. at 826. The Court also indicated that the Virginia courts should have initially permitted the appellant to raise an overbreadth challenge to the statute, $i d$. at 815-17, since " 'pure speech' rather than conduct was involved," see Broaderick v. Oklahoma, 413 U.S. 601, 615-16 (1973), and because noncommercial speech such as encouragement of abortions by doctors, husbands, and lecturers seemed to be within the terms of the statute. See note 57 supra. Since the statute was amended after Bigelow's conviction to prohibit only advertisements for illegal abortions performed in Virginia, VA. CoDE $§ \S 18.1-62.1, .3$ (Supp. 1975), the Court found the overbreadth issue moot "as a practical matter" since the statute's pre-1972 form would not be applied again. 421 U.S. at 817-18. However, even in its amended form the statute was not limited to commercial solicitation of abortions. It therefore remained overbroad and continued to impose a chilling effect on the petitioner that should have been sufficient to allow an overbreadth challenge. See Note, The First Amendment Overbreadth Doctrine, 83 HARv. L. REv. 844, 848 (1970). 
macy v. Virginia Citizens Consumer Council, ${ }^{70}$ the Court invalidated a statute subjecting licensed pharmacists to penalties for "unprofessional conduct" if they advertised the prices of prescription drugs. ${ }^{71}$ The Court did not attempt to differentiate drug price advertisements from speech that does "no more than propose a commercial transaction," 72 but found that the advertisements were "of value" 73 to consumers. Advertised drug prices would aid indigent or elderly consumers who might not have the means for comparison shopping, ${ }^{74}$ and would benefit society as a whole by facilitating the efficient allocation of resources ${ }^{75}$ and providing factual information

70 S. Ct. 1817 (1976). Seven Justices joined the majority; Justice Rehnquist dissented and Justice Stevens did not take part.

$"$ VA. CoDE. $§ 54-524.35$ (1974). The statute provided that a licensed pharmacist is guilty of unprofessional conduct if he "(3) publishes, advertises or promotes, directly or indirectly, in any manner whatsoever, any amount, price, fee, premium, discount, rebate or credit terms . . . for any drugs which may be dispensed only by prescription." Penalties consisted of a fine or revocation or suspension of the pharmacist's license. VA. CoDE $§ 54-524.22: 1$ (1974).

The constitutionality of the statute had previously been upheld against a first amendment, due process, and equal protection challenge brought by licensed pharmacists. Patterson Drug Co. v. Kingery, 305 F. Supp. 821 (W.D. Va. 1969). In Virginia Board of Pharmacy, the statute was attacked by consumers; the Court found that the consumers had standing to challenge the statute because of their first amendment right to receive drug price information. 96 S. Ct. 1823; see Procunier v. Martinez, 416 U.S. 396, 408-09 (1974); Lamont v. Postmaster Gen., 381 U.S. 301 (1965). See also Comment, The Right to Receive and the Commercial Speech Doctrine: New Constitutional Considerations, 63 GEo. L.J. 775 (1975).

7296 S. Ct. at 1826,1830 n. 24 (1976).

${ }^{73}$ Id. at 1821.

74 The Court observed that "the particular consumer's interest in the free flow of commercial information . . . may be as keen, if not keener by far, than his interest in the day's most urgent political debate." Id. at 1826. The Court also noted that the advertiser's "purely economic" interest did not disqualify him from first amendment protection, citing first amendment-labor relations cases for support. Id. at 1826, citing NLRB v. Gissel Packing Co., 395 U.S. 575 (1969); NLRB v. Virginia Elec. \& Power Co., 314 U.S. 469 (1941); AFL v. Swing, 312 U.S. 321 (1941); Thornhill v. Alabama, 310 U.S. 88 (1940).

${ }^{75}$ Id. at 1827; see Dun \& Bradstreet, Inc. v. Grove, 404 U.S. 898, 904-05 (1971) (Douglas, J., dissenting from denial of certiorari). The Court's ruling that the microeconomic functions performed by commercial speech constitute interests protected by the first amendment is a novel addition to the list of interests traditionally thought to have first amendment protection. See text and notes at notes 121-30 infra. Justice Rehnquist, in dissent, found "nothing in the United States Constitution which requires the Virginia Legislature to hew to the teachings of Adam Smith in its legislative decisions regulating the pharmacy profession." 96 S. Ct. at 1836. This observation evokes Justice Holmes's dissent in Lockner v. New York, 198 U.S. 45, 75 (1905) ("The Fourteenth Amendment does not enact Mr. Herbert Spencer's Social Statics"), and suggests that the Court's recognition of resource allocation as a constitutionally protected interest, at least when "speech" is involved, portends a partial return to Lockner's substantive due process review of business regulation. However, the Court's decision to accord a measure of first amendment protection to commercial speech can be justified on traditional first amendment grounds, see, e.g., Redish, The First Amendment in the Marketplace: Commercial Speech and the Values of Free Expression, 39 GEo. WaSH. L. REv. 429 (1971); text and notes at notes 120-70 infra, an approach that avoids the substantive due process overtones of the majority opinion. 
relevant to public discussion of controversial economic questions. ${ }^{76}$ Balancing the first amendment interests of pharmacists, consumers, and society against the justifications advanced for the statute-preventing ruinous price competition that would endanger the quality of pharmaceutical services ${ }^{77}$ and protecting the professional image of pharmacists ${ }^{78}$ - the Court held that the regulation violated the first amendment. ${ }^{79}$ For the first time, the Court expressly ruled that a purely commercial advertisement enjoys some first amendment protection. ${ }^{80}$

Neither Bigelow nor Virginia Board of Pharmacy represents significant progress beyond Pittsburgh Press in defining commercial speech. Part of the explanation for this shortcoming may be that Justice Blackmun, author of the majority opinions in Bigelow and Virginia Board of Pharmacy, was anxious to destroy any vestiges of the two-level theory of commercial speech. ${ }^{81}$ Both opinions contain

${ }^{76} 96 \mathrm{~S}$. Ct. at 1826; id. at $1835 \mathrm{n} .8$ (Stewart, J., concurring). The Court cited three cases involving commercial advertising containing information of general public interest: Bigelow v. Virginia, 421 U.S. 809 (1975); Fur Information \& Fashion Council, Inc. v. E.F. Timme \& Son, 364 F. Supp. 16 (S.D.N.Y. 1973) (advertising campaign by manufacturers of synthetic furs implicitly accusing the fur industry of endangering species of fur-bearing animals), aff'd, 501 F.2d 1048 (2d Cir.), cert. denied, 419 U.S. 1022 (1974); Chicago Joint Bd. v. Chicago Tribune Co., 435 F.2d 470 (7th Cir. 1970) (union attempt to compel newspaper to accept advertisement opposing importation of foreign-made clothing), cert. denied, 402 U.S. 973 (1971).

$7796 \mathrm{~S}$. Ct. at 1828-29. The state's argument was that limiting aggressive price competition would enable pharmacists to provide expensive services of compounding, handling, and dispensing prescription drugs, which might be neglected if price competition led to costcutting measures. The Court found little merit in the argument, noting that "nothing prevents the 'professional' pharmacist from marketing his own assertedly superior product, and contrasting it with that of the low-cost, high-volume prescription drug retailer." Id. at 1829. The Court also implied that the state could directly regulate "cut-throat" competition under the doctrine of Parker v. Brown, 317 U.S. 341 (1943).

${ }^{78} 96 \mathrm{~S}$. Ct. at 1829.

$7996 \mathrm{~S}$. Ct. at 1828-29. The Court observed that one social interest commonly advanced in support of prohibition of advertising for specific goods and products-the reduction of public demand for potentially harmful or dangerous products-was unavailable to the state in this case since the pharmaceuticals involved could be obtained only with a physician's prescription. Id. at $1828 \mathrm{n} .21$. But see id. at 1829 (Rehnquist, J., dissenting). See also Terminal-Hudson Elecs., Inc. v. Dep't of Consumer Affairs, 407 F. Supp. 1075 (C.D. Cal. 1976), vacated, 96 S. Ct. 2619 (1976).

* [T] he question whether there is a First Amendment exception for "commercial speech" is squarely before us. Our pharmacist does not wish to editorialize on any subject, cultural, philosophical, or political. He does not wish to report any particularly newsworthy fact, or to make generalized observations even about commercial matters. The "idea" he wishes to communicate is simply this: "I will sell you the X prescription drug at the Y price."

$96 \mathrm{~S}$. Ct. at 1825 . The Court ruled that such expression does not lack "all protection." Id. at 1826.

${ }^{21}$ This purpose is clearly evidenced in the following key passage: 
language broadly condemning the idea that advertising can be divided into distinct categories of commercial and noncommercial speech. ${ }^{82}$ And the majority opinion in Virginia Board of Pharmacy evidences outright revisionism in asserting that Pittsburgh Press was based not on a distinction between commercial and other types of speech, but only on the illegality of the discriminatory employment proposals in the advertisements and the newspaper layout. ${ }^{83}$ These passages leave the impression that the Court is moving away from the premise that commercial speech is a special category with a unique status in constitutional law.

Yet the Court did not carry through its efforts to undermine a distinct category of commercial speech. In the concluding paragraphs of both Bigelow ${ }^{84}$ and Virginia Board of Pharmacy, ${ }^{85}$ the majority recognized that in certain contexts, such as regulation of false or deceptive advertising, cogent reasons exist for distinguishing between commercial advertising and other speech. The Court expressly indicated that in these contexts, commercial speech would continue to receive less than full protection. ${ }^{86}$

The Court was working at cross-purposes in emphasizing the difficulties of defining commercial speech yet requiring that in certain contexts courts continue to observe the distinction. These conflicting thrusts underlie some of the confusion in the opinions, particularly in Bigelow. ${ }^{87}$ In determining whether the offending adver-

Our question is whether speech which does "no more than propose a commercial transaction," Pittsburgh Press Co. v. Pittsburgh Comm'n on Human Relations, 413 U.S., at $385, \ldots$ is so removed from any "exposition of ideas," Chaplinsky v. New Hampshire, 315 U.S. $568,572, \ldots$. (1942), and from " "truth, science, morality, and the arts in general, in its diffusion of liberal sentiments on the administration of Government." "Roth v. United States, 354 U.S. 476, 484, . . (1957), that it lacks all protection. Our answer is that it is not.

Id. at 1826. Chaplinsky and Roth are leading cases adopting the two-level theory. See note 28 supra. The effect of divorcing the Pittsburgh Press characterization of commercial speech from the rulings in these cases is to disassociate the commercial speech doctrine from the twolevel theory.

${ }_{82}$ See Virginia State Bd. of Pharmacy v. Virginia Citizens Consumer Council, $96 \mathrm{~S}$. Ct. 1817, 1827 (1976); Bigelow v. Virginia, 421 U.S. 809, 826 (1975).

$8396 \mathrm{~S}$. Ct. at 1824 .

${ }^{84} 421$ U.S. at 828 . The Court suggested that the regulation might have been upheld if the advertisement had been deceptive or fraudulent, had "related to a commodity or service that was then illegal," or had "otherwise furthered a criminal scheme." Id. The Court also suggested that commercial advertising can be regulated to protect citizens' privacy rights or to shield a captive audience. Id.

${ }^{85} 96 \mathrm{~S}$. Ct. at 1830-31; see text at notes 101-02 infra.

${ }^{86} 96 \mathrm{~S}$. Ct. at $1830 \mathrm{n} .24$.

${ }^{87}$ The lower courts divided after Bigelow as to whether the Court's emphasis on the public interest element of the advertisement signified that a narrow category of commercial speech remained per se unprotected. For cases interpreting Bigelow as having abolished a 
tisement ${ }^{88}$ in that case was commercial speech, the Court followed the method used in Pittsburgh Press ${ }^{89}$ comparing the advertisement with the "commercial" advertisements in Chrestensen and Pittsburgh Press and the "editorial" advertisement in New York Times. The analysis revealed "important differences between the advertisement presently at issue and those involved in Chrestensen and Pittsburgh Press."

The advertisement published in appellant's newspaper did more than simply propose a commercial transaction. It contained factual material of clear "public interest." Portions of its message, most prominently the lines, "Abortions are now legal in New York. There are no residency requirements," involve the exercise of the freedom of communicating information and disseminating opinion. ${ }^{91}$

distinct category of unprotected commercial speech, see Terminal-Hudson Elecs., Inc. v. Department of Consumer Affairs, 407 F. Supp. 1075, 1078 (C.D. Cal.), vacated, 96 S. Ct. 2619 (1976); Anderson, Clayton \& Co. v. Washington State Dep't of Agriculture, 402 F. Supp. 1253, 1256-57 (W.D. Wash. 1975); Planned Parenthood Ass'n v. Fitzpatrick, 401 F. Supp. 554, 557 (E.D. $\mathrm{Pa} .1975$ ). For opinions reading Bigelow as preserving a narrow category of unprotected purely commercial speech, see Terminal-Hudson Elecs., Inc. v. Department of Consumer Affairs, 407 F. Supp. 1075, 1082 (C.D. Cal.), vacated, 96 S. Ct. 2619 (1976) (dissenting opinion); Wortham v. Dun \& Bradstreet, Inc., 399 F. Supp. 633, 638 n.2 (S.D. Tex. 1975); Population Servs. Int'l v. Wilson, 398 F. Supp. 321, 337 (S.D.N.Y. 1975), prob. juris. noted, 96 S. Ct. 2621 (1976); Urowsky v. Board of Regents, 38 N.Y.2d 364, 369-70, 342 N.E.2d 583, 586, 379 N.Y.S.2d 815, 819-20 (1975).

In Virginia Board of Pharmacy, the Court acknowledged the ambiguity left by Bigelow in noting that "some fragment of hope for the continuing validity of a 'commercial speech' exception arguably might have persisted because of the subject matter of the advertisement in Bigelow." $96 \mathrm{~S}$. Ct. at 1825 . The Court decisively resolved the ambiguity by stating that speech will no longer be held unprotected simply because it is "commercial." Id. at 1825-27.

** The advertisement consisted of particular information about a New York abortion referral agency, and general information about the availability of legal abortions in New York: UNWANTED PREGNANCY

LET US HELP YOU

Abortions are now legal in New York.

There are no residency requirements,

FOR IMMEDIATE PLACEMENT IN ACCREDITED

HOSPITAL AND CLINICS AT LOW COST

Contact

WOMEN'S PAVILION

515 Madison Avenue

New York, N.Y. 10022

STRICTLY CONFIDENTIAL. We will make all arrangements for you and help you with information and counseling.

421 U.S. at $812(1975)$.

* See text at notes 44-46 supra.

90 421 U.S. at $821-22$.

"Id. at 822 . The phrase "public interest" refers to the Court's characterization of the 
If the Court was equating the advertisement in Bigelow with the advertisement in New York Times, and thereby placing it outside the category of commercial speech, the remainder of the opinion is inexplicable. The advertisement in New York Times was "entitled to the same degree of constitutional protection as ordinary speech." ${ }^{92}$ The advertisement in Bigelow, however, was hardly treated as "ordinary speech." If the speech promoting the abortion agency had been fully protected, Virginia's justification for punishing it would have been subject to strict scrutiny ${ }^{93}$ under the test of Brandenburg $v$. Ohio, ${ }^{94}$ which measures the legitimacy of speech inciting unlawful activities. But the Court found Brandenburg inapposite $^{95}$ and applied a balancing test requiring only that the governmental interest "outweigh" the value of the advertising..$^{96}$ By applying this test, the Court gave the advertisement the same amount of protection that Pittsburgh Press suggested commercial speech was due. ${ }^{97}$

It is more satisfactory to read the passage distinguishing the advertisement in Bigelow from those in Chrestensen and Pittsburgh

advertisement in New York Times as concerning matters "of the highest public interest and concern." New York Times Co. v. Sullivan, 376 U.S. 254, 266 (1964), quoted in Bigelow v. Virginia, 421 U.S. 809, 821 (1975). Justice Blackmun also noted that Bigelow's advertisement "conveyed information of potential interest and value" to those with a general curiosity about abortion and its legal status and to those seeking reform in Virginia. The advertisement was therefore "not unnewsworthy." Id.

This passage created the impression that the Court was adopting a "public interest" test for distinguishing protected from unprotected advertising. See cases cited in note 87 supra; The Supreme Court, 1974 Term, 89 Harv. L. Rev. 47, 116-18 (1975); 61 Cornell L. Rev. 640, 646-48 (1976); 42 TENN. L. REv. 573, 579-81 (1975). Under this reading of Bigelow, the decision creates a remarkable "three-level" theory of commercial speech: unprotected purely commercial speech; commercial speech of "public interest" granted some protection; and editorial advertisements having full first amendment protection. Cf. Population Servs. Int'l v. Wilson, 398 F. Supp. 321, 337 (S.D.N.Y. 1975), prob. juris. noted, 96 S. Ct. 2621 (1976) (dividing advertisements into "purely commercial," "mixed," and "editorial"). Even if this interpretation is correct, Virginia Board of Pharmacy ended the three-level theory by establishing that purely commercial advertising also enjoys some protection. See text and note at note 80 supra.

${ }^{92} 421$ U.S. at 820 (1975); see New York Times Co. v. Sullivan, 376 U.S. 254, 266 (1964).

${ }^{93}$ See note 23 supra.

" 395 U.S. 444 (1969); see note 197 infra. In Holiday Magic Inc. v. Warren, 357 F. Supp. 20, 24 (E.D. Wis. 1973), vacated on other grounds, 497 F.2d 687 (7th Cir. 1974), the application of the Brandenburg test in the commercial speech context was specifically rejected. For an unusual case applying a clear and present danger analysis to a commercial advertising prohibition, see Mitchell Family Planning, Inc. v. City of Royal Oak, 335 F. Supp. 738, 742 (E.D. Mich. 1972). The decision is criticized for ignoring Chrestensen and subsequent commercial speech cases in 51 N.C.L. REv. 581 (1973).

${ }^{\text {os }} 421$ U.S. at 819.

"Id. at 826 .

"7ee text and notes at notes 52-55 supra. 
Press as suggesting that the "public interest" value of commercial advertising be assessed on a case-by-case basis. Under this approach, a generalized judgment about the nature and value of commercial advertising might seem unnecessary. ${ }^{98}$ However, as long as the Court does not question the holding of New York Times that editorial advertisements are entitled to full protection without a case-by-case assessment of their "public interest" value, a threshold distinction between commercial and editorial advertising is required to determine when a case-by-case approach should be applied.

The pattern of denying and then reaffirming the existence of a commercial speech category is also apparent in Virginia Board of Pharmacy. In discussing the first amendment value of advertising the retail prices of prescription drugs, the Court returned to the theme of Bigelow in stressing that commercial advertising may contain not only purely economic information but also information of general public interest. ${ }^{99}$ The suggested consequence was that "no line between publicly 'interesting' or 'important' commercial advertising and the opposite kind could ever be drawn." 100 Despite this difficulty, the Court recognized, as it had in Bigelow, that there are areas where regulation of commercial advertising is "surely permissible," ${ }^{101}$ giving as examples time, place, and manner restrictions on the distribution of commercial speech, regulations of false or deceptive advertising, and regulations of advertising for illegal transactions. ${ }^{102}$ In a footnote the Court made explicit the continuing viability of a commercial speech distinction in these contexts.

In concluding that commercial speech enjoys First Amendment protection, we have not held that it is wholly undifferentiable from other forms. There are commonsense differences between speech that does "no more than propose a commercial transaction," Pittsburgh Press Co. v. Pittsburgh Comm'n on Human Relations, 413 U.S. at 385 . . . , and other varieties. Even if the differences do not justify the conclusion that commercial speech is valueless, and thus subject to complete suppression by the State, they nonetheless suggest that a different degree

${ }_{98}$ This interpretation is reinforced by Virginia State Bd. of Pharmacy v. Virginia Citizens Consumer Council, 96 S. Ct. 1817, 1827 (1976) (noting that the degree of public interest content in advertising varies widely).

${ }^{99}$ See note 76 supra.

$10096 \mathrm{~S}$. Ct. at 1827.

101 Id. at 1830.

${ }^{102}$ Id. at $1830-31$. 
of protection is necessary to insure that the flow of truthful and legitimate commercial information is unimpaired. ${ }^{103}$

Bigelow and Virginia Board of Pharmacy essentially vindicate the position suggested by Justice Powell in dictum in Pittsburgh Press: there is a distinct category of commercial speech that enjoys some, but not full, first amendment protection. ${ }^{104}$ Neither case, however, gives a working definition of commercial speech. The difficult problem of determining the elements that define commercial speech, left open by Pittsburgh Press, remains.

\section{The Definition of Commercial Speech after Virginia Board of PhARMACY}

\section{A. The Supreme Court's Rationale for Allowing Greater Regulation of Commercial Speech}

In Virginia Board of Pharmacy, the Supreme Court was anxious to ensure that its decision would not be read as questioning the constitutionality of regulations of false and deceptive advertising. ${ }^{105}$ Justice Stewart's concurring opinion develops a first amendment justification for regulating deceptive advertising more rigorously than deceptive speech outside the commercial context, ${ }^{106}$ and Justice Blackmun's majority opinion contains a similar but less extensive justification. ${ }^{107}$ Together, these opinions offer a tentative rationale for according reduced first amendment protection to commercial advertising and provide an appropriate place to begin an effort to define commercial speech. ${ }^{108}$

Justices Stewart and Blackmun suggest five factors that distinguish commercial speech and justify regulating it more rigorously than other varieties of speech.

(1) The advertiser of commercial commodities and services has better access to the facts concerning his product than the media have to the facts in their news reports, which may be drawn from sketchy or conflicting sources. ${ }^{108}$

${ }^{103}$ Id. at 1830 n. 24 .

104 See Bigelow v. Virginia, 421 U.S. 809, 821 (1975) (quoting with approval the dictum in Pittsburgh Press Co. v. Pittsburgh Comm'n on Human Relations, 413 U.S. 376, 389 (1973)).

${ }_{105}$ See Virginia State Bd. of Pharmacy v. Virginia Citizens Consumer Council, 96 S. Ct. 1817, 1830-31 (1976).

${ }^{106} I d$. at $1832-35$.

${ }^{107}$ Id. at $1830-31 \&$ n.24.

${ }^{108}$ Although Justices Blackmun and Stewart emphasized different criteria, their approaches are not contradictory, and Chief Justice Burger's concurrence made no objection to any of the factors mentioned. See id. at 1831-32.

${ }^{109}$ Id.at 1830 n.24 (Blackmun, J.); id. at 1833 (Stewart, J., concurring). 
(2) The factual assertions in commercial advertising relate to tangible goods and services that are more susceptible to empirical testing by regulatory authorities than are representations made in news reports and editorials. ${ }^{110}$

(3) The importance of advertising in generating profits makes it less susceptible to the chilling effect of governmental regulation than news reporting and editorializing. ${ }^{111}$

(4) The advertiser of commercial commodities and services does not have to assemble the facts about his product under time pressure as do media distributors with publication deadlines for topical material. ${ }^{112}$

(5) Commercial speech has lower first amendment value than reports of news and expressions of opinion since commercial advertising generally makes no express contribution to the forum of ideas. ${ }^{113}$

An examination of these distinguishing characteristics reveals serious drawbacks in using most of them as a foundation for defining commercial speech. First, although regulations of commercial advertising often apply not only to business advertisers but also to the media distributing such advertisements, ${ }^{114}$ some of the factors listed by the Court are irrelevant to regulations directed against the media as distributors of advertising. The media have less access than business advertisers to the facts about commercial products and services (factor 1) and thus may not have the opportunity to objectively resolve factual questions about commercial products and services (factor 2). In general, newspapers and broadcasters have less access to information about products and services appearing in commercial advertisements they disseminate than they do to facts in the news stories their reporters have investigated.

In addition, the media's financial interest in commercial adver-

${ }^{110}$ Id. at 1835 (Stewart, J., concurring); See Developments in the Law-Deceptive Advertising, 80 HaRv. L. REv. 1005, 1030-31 (1967).

III Id. at 1830 n.24 (Blackmun, J.).

112 Id. at 1833 (Stewart, J., concurring).

${ }^{113}$ Id. at 1834-35 (Stewart, J., concurring); id. at 1827 \& n.19 (by implication).

114 This was the case in Bigelow v. Virginia, 421 U.S. 809 (1975), and Pittsburgh Press Co. v. Pittsburgh Comm'n on Human Relations, 413 U.S. 376 (1973). In contexts such as prohibitions of advertising for particular harmful or illegal products, the media must be included in the regulatory scheme in order to police it effectively. Regulating advertisers alone is inadequate because an advertiser might not remain in the jurisdiction of the regulating government long enough to be subject to service of process, and because advertisers might be so numerous that enforcement would be impossible unless the media were also subject to regulation. See, e.g., Pittsburgh Press Co. v. Pittsburgh Comm'n on Human Relations, 413 U.S. 376 (1973). 
tising (factor 3)-earning revenue through the sale of advertising ${ }^{115}$-is likely to be insignificant for any particular advertisement or line of advertising in comparison with the financial interest of the advertiser. A business advertiser may have such an important and enduring financial interest in promotional advertising that the expense and delay in overcoming regulatory obstacles to his advertisements will not deter him from taking all available measures to secure his rights. In contrast, the media are unlikely to have a sufficient financial interest in any particular advertisement to overcome the chilling effect of such regulation. ${ }^{116}$

A second difficulty with using the Court's factors as a basis for defining commercial speech is that several of them are factual generalizations that do not hold true in specific cases. The financial incentives of a business to secure its right to advertise (factor 3 ) will vary with the financial returns expected from particular advertising programs. A gasoline service station operator hardly has the incentive to challenge governmental action against a deceptive advertisement that a large oil corporation has to challenge action affecting a national advertising campaign. Moreover, it is not always true that business advertisers face less severe publication deadlines than the news media (factor 4), since market conditions, and therefore advertising copy, can change quite rapidly in some industries, such as grocery retailing. The assertion that factual questions about commercial commodities and services can be objectively resolved by empirical testing (factor 2) is also suspect, as the frequent disputes over the qualities of products in Food and Drug Administration proceedings demonstrate. ${ }^{117}$

Factors 1 through 4 of the Supreme Court's rationale for the permissible regulation of false and deceptive commercial speech are more relevant to the reasonableness of regulations than to a prelimi-

${ }^{115}$ Some courts have characterized the media's interest in advertising as purely financial, as opposed to the advertiser who also has an interest in conveying a certain message. See United States v. Hunter, 459 F.2d 205, 212 (4th Cir.), cert. denied, 409 U.S. 934 (1972); Capital Broadcasting Co. v. Mitchell, 333 F. Supp. 582, 584 (D.D.C. 1971), aff'd, 405 U.S. 1000 (1972); cf. Lehman v. City of Shaker Heights, 418 U.S. 298 (1974) (city that limited access to advertising space on buses to commercial speech was acting in a "proprietary" capacity). See also De Vore \& Nelson, Commercial Speech and Paid Access to the Press, 26 HASTINGS L.J. 745 (1975).

116 On occasion the media's financial interest in a particular type of advertising has been sufficiently strong to induce a challenge to its prohibition. See, e.g., New York State Broadcasters Ass'n v. United States, 414 F.2d 990 (2d Cir. 1969), cert. denied, 396 U.S. 1061 (1970) (state lottery advertising); Capital Broadcasting Co. v. Mitchell, 333 F. Supp. 582 (D.D.C. 1971), aff'd, 405 U.S. 1000 (1972) (cigarette commercials).

11 A recent example is the controversy surrounding the FDA's decision to ban the use of food coloring Red No. 2. N.Y. Times, Feb. 29, 1976, § 1, at 20, col. 1. 
nary definition of commercial speech. These factors represent the kind of contextual considerations courts should weigh in the balancing test set forth in Bigelow ${ }^{118}$ and Virginia Board of Pharmacy. ${ }^{119}$ The factors should not be incorporated in the threshold question whether it is appropriate to apply a balancing test rather than the strict scrutiny standard employed in assessing regulation of fully protected speech. Factor 5 of the Court's rationale-the reduced first amendment value of commercial advertising-is a more promising basis for deriving a definition of commercial speech.

\section{B. A Definition Derived from the Lower Value of Commercial Speech}

In suggesting that the lower value of commercial advertising allows more rigorous regulation of commercial speech than other varieties of speech, ${ }^{120}$ the Court posited an inverse relationship between the value of speech and the permissible degree of regulation. ${ }^{121}$ The idea that different types of expression have different degrees of first amendment value is fundamental to the Supreme Court's explication of the first amendment. The Court has declared that the central purpose of the first amendment is to protect political expression ${ }^{122}$-in Professor Meikeljohn's terms, "speech which bears, directly or indirectly, upon issues with which voters have to deal." ${ }^{123}$ The Court has of course recognized that

118421 U.S. at 826.

$11996 \mathrm{~S}$. Ct. at 1826-30.

120 See note 113 supra.

121 This premise is also apparent in Young v. American Mini Theatres, Inc., $96 \mathrm{~S}$. Ct. 2440 (1976), where Justice Stevens, writing for the plurality, found that the lower first amendment value of nonobscene but "sexually explicit" adult films justifies more restrictive zoning of adult theaters than of ordinary movie houses. The plurality opinion found support for this position in Virginia Board of Pharmacy, where "[a]s Mr. Justice Stewart pointed out . . . the 'difference between commercial price and product advertising . . . and ideological communication' permits regulation of the former that the First Amendment would not tolerate with respect to the latter." Id. at $2451 \mathrm{n} .31$. Justice Stevens's view that sexually explicit speech is more susceptible to regulation was a minority position, joined by Chief Justice Burger and Justices White and Rehnquist. However, one of the dissenters, Justice Stewart, specifically advocated more rigorous regulation of commercial speech in Virginia State Bd. of Pharmacy v. Virginia Citizens Consumer Council, 96 S. Ct. 1817, 1832-35 (1976). Thus, at least five justices (six if Justice Blackmun is added) have recognized that the lower value of commercial speech justifies regulating it more rigorously.

${ }^{122}$ See, e.g., Buckley v. Valeo, 96 S. Ct. 612, 632 (1976); Monitor Patriot Co. v. Roy, 401 U.S. 265, 272 (1971); Mills v. Alabama, 384 U.S. 214, 218 (1966); Garrison v. Louisiana, 379 U.S. 64, 74-75 (1964); New York Times Co. v. Sullivan, 376 U.S. 254, 270 (1964).

${ }^{123}$ A. Meiklejohn, Political Freedom 79 (1960). Under the Meiklejohn view, commercial advertising would be entitled only to "due process" protection as "private speech." Id. at 79, 83; see Hastie, Free Speech: Contrasting Constitutional Concepts and their Consequences, 9 HaRv. C.R.-C.L. L. REv. 428 (1974). 
other desirable ends are served by the first amendment, ${ }^{124}$ such as furthering the search for truth and maximizing individual selfexpression, and has extended first amendment protection beyond the discussion of political subjects ${ }^{125}$ and the expression of ideas. ${ }^{126}$ Nevertheless, when the Court has denied first amendment protection to particular categories of speech, such as obscenity ${ }^{127}$ and "fighting words," 128 it has relied on the low value of such speech in aiding the search for truth, advancing self-expression, but above all, contributing to democratic self-government. ${ }^{129}$

Courts have long recognized that commercial advertising has lower first amendment value than traditionally protected forms of expression. ${ }^{130}$ In Bigelow and Virginia Board of Pharmacy the Court reaffirmed this principle in acknowledging that as a rule commercial advertising does not make "any direct contribution to the interchange of ideas," but only to private economic decision making and public allocation of resources. ${ }^{131}$ However, the Court recognized that commercial advertising indirectly contributes to the ends traditionally served by the first amendment by supplying the public with information, images, and values that may enter into the discussion

124 See generally Karst, Equality as a Central Principle in the First Amendment, 43 U. CHI. L. Rev. 20, 23 (1975); Emerson, Toward a General Theory of the First Amendment, 72 Yale L.J. 877, 884-87 (1963); Meiklejohn, The First Amendment is an Absolute, 1961 Sup. CT. REv. 245, 256-57.

125 See, e.g., UMW District 12 v. Illinois State Bar Ass'n, 389 U.S. 217, 223 (1967); Time, Inc. v. Hill, 385 U.S. 376, 388 (1967).

126 See, e.g., Buckley v. Valeo, 96 S. Ct. 612, 632 (1976); Stanley v. Georgia, 394 U.S. 557, 566 (1969); Winters v. New York, 333 U.S. 507, 510 (1948).

${ }^{127}$ Miller v. California, 413 U.S. 15 (1973); Roth v. United States, 354 U.S. 476 (1957).

12x Gooding v. Wilson, 405 U.S. 518 (1972); Chaplinsky v. New Hampshire, 315 U.S. 568 (1942).

129 See Miller v. California, 413 U.S. 15, 34-35 (1973). See also note 28 supra.

130 The traditional view of the first amendment value of commercial advertising was expressed by Chief Judge Bazelon in Banzhaf v. FCC, 405 F.2d 1082, 1101-02 (D.C. Cir. 1968), cert. denied, 396 U.S. 842 (1969).

Promoting the sale of a product is not ordinarily associated with any of the interests the First Amendment seeks to protect. As a rule, it does not affect the political process, does not contribute to the exchange of ideas, does not provide information on matters of public importance, and is not, except perhaps for the ad-men, a form of individual selfexpression.

See Lehman v. City of Shaker Heights, 418 U.S. 298, 314 (1974) (Brennan, J., dissenting); Pittsburgh Press Co. v. Pittsburgh Comm'n on Human Relations, 413 U.S. 376, 385 (1973); Columbia Broadcasting Sys., Inc. v. Democratic Nat'l Comm., 412 U.S. 94, 201 (1973) (Brennan, J., dissenting); New York Times Co. v. Sullivan, 376 U.S. 254, 266 (1964); Holiday Magic, Inc. v. Warren, 357 F. Supp. 20, 24-26 (E.D. Wis. 1973), vacated, 497 F.2d 687 (7th Cir. 1974).

131 Virginia State Bd. of Pharmacy v. Virginia Citizens Consumer Council, 96 S. Ct. 1817, 1827 (1976); id. at 1835 n.8 (Stewart, J., concurring); Bigelow v. Virginia, 421 U.S. 809, 822 (1975). 
of public issues and the creation of works of artistic expression. ${ }^{132}$

This insight into the indirect first amendment value of commercial speech was partially responsible for the Court's rejection in Virginia Board of Pharmacy of a case-by-case "public interest" test for determining whether particular advertisements are entitled to some first amendment protection. The Court expressed doubt that a clear line between "publicly 'interesting' or 'important' advertising and the opposite kind could ever be drawn." ${ }^{133}$ Another reason the Court rejected the public interest test was that such a distinction would be difficult to enforce. A commercial advertiser confronted with a prohibition of advertising for his product would only have to "append a civic appeal, or a moral platitude, to achieve immunity from the law's command." 134 To prevent evasion of advertising regulations through sham editorializing, the courts would have to delve into an advertiser's motives, in effect using a different form of the primary purpose test. ${ }^{135}$ Although the Court in Virginia Board of Pharmacy raised these objections against a test for distinguishing unprotected from partially protected commercial speech, the arguments apply as well to a test for distinguishing partially protected commercial speech from fully protected speech.

The difficulties in drawing a line between advertising that con-

${ }^{132}$ In Virginia Board of Pharmacy the Court also noted that commercial speech may have first amendment value because it assists consumers in making purchasing decisions and thus facilitates the efficient allocation of resources. See text and notes at notes 73-75 supra. Although these functions of advertising may provide support for according some first amendment protection to commercial speech, it can hardly be said that all advertising increases the flow of valuable information to consumers. Obviously, a false advertisement does not assist consumers in making the proper economic decision. See Virginia State Bd. of Pharmacy v. Virginia Citizens Consumer Council, 96 S. Ct. 1817, 1830-31 (1976). Because all commercial advertising does not faciliate the allocation of resources, this value cannot serve as the basis for a definition of commercial speech.

${ }^{133} 96$ S. Ct. at 1827. Bigelow v. Virginia, 421 U.S. 809 (1975), decided less than a year earlier, was widely interpreted as having adopted a "public interest" test for measuring the degree of protection to be accorded to commercial advertising. See notes $87 \& 91$ supra. The Court's rejection of a "public interest" test for commercial speech parallels the development of the New York Times libel privilege. In Rosenbloom v. Metromedia, Inc., 403 U.S. 29 (1971), the plurality adopted a public interest test for determining when to apply the actual malice standard. The test was rejected in Gertz v. Robert Welch, Inc., 418 U.S. 323 (1974), because of "the difficulty of forcing state and federal judges to decide on an ad hoc basis which publications address issues of 'general or public interest' and which do not-to determine . . . 'what information is relevant to self-government.' . . . We doubt the wisdom of committing this task to the consciences of judges." Id. at 346.

${ }_{134}$ Bigelow v. Virginia, 421 U.S. 809, 832 (1975) (Rehnquist, J., dissenting), quoting Valentine v. Chrestensen, 316 U.S. 52, 55 (1942); see Virginia State Bd. of Pharmacy v. Virginia Citizens Consumer Council, 96 S. Ct. 1817, 1827 (1976); 8 IND. L. Rev. 890, 896 (1975)

${ }^{135}$ See text and notes at notes 25-26 supra. 
tains information and opinion of public interest and "purely commercial" advertising should not lead the courts to ignore the important differences between editorial advertising and commercial hucksterism in formulating a definition of commercial speech. An appropriate definition of commercial speech should reflect its lower order of value as well as provide workable guidance to courts, agencies, and advertisers. Three possible definitions may meet these goals.

1. Speech that does no more than propose a commercial transaction. The "classic example" of commercial speech mentioned in Pittsburgh Press ${ }^{136}$ and Virginia Board of Pharmacy ${ }^{137}$ is an obvious definitional candidate. ${ }^{138}$ Since most commercial proposals directly contribute only to the allocation of private resources, not to the formation of public opinion, speech that does "no more than propose a commercial transaction" shares the indicium of low value the Court has perceived in commercial speech. If this definition requires an express proposal of a commercial transaction, ${ }^{139}$ however, it is seriously underinclusive. Few television or billboard advertisements expressly propose a commercial transaction; yet these forms of advertising frequently have no more traditional first amendment value than advertisements that do contain a proposal, such as the want ads in Pittsburgh Press or the drug price advertisements in Virginia Board of Pharmacy.

This underinclusiveness can be repaired by interpreting the definition to encompass implied as well as express commercial pro-

${ }_{136}$ Pittsburgh Press Co. v. Pittsburgh Comm'n on Human Relations, 413 U.S. 376, 385 (1973); see text at notes 45-46 supra.

${ }_{137}$ Virginia State Bd. of Pharmacy v. Virginia Citizens Consumer Council, 96 S. Ct. 1817, 1826,1830 n.24 (1976).

${ }^{138}$ For cases implicitly adopting the commercial proposal definition of commercial speech, see Linmark Assocs., Inc. v. Township of Willingboro, 535 F.2d 786, 796 (3d Cir. 1976), cert. granted, 45 U.S.L.W. 3240 (U.S. Nov. 9, 1976); Baird v. La Follette, 72 Wis. 2d 1, 239 N.W.2d 536 (1976); Economy Carpets Mfrs. \& Distribs., Inc. v. Better Business Bureau, 330 So. 2d 301 (La. 1976); Urowsky v. Board of Regents, 38 N.Y.2d 364, 342 N.E.2d 583, 379 N.Y.S.2d 815, 820 (1975).

${ }^{139}$ The Court's use of "express language" tests to measure first amendment rights has been confined to fully protected speech. For example, in Buckley v. Valeo, $96 \mathrm{~S}$. Ct. 612, 64647 (1976), the Court, construing vague language in the Federal Election Campaign Act limiting expenses made "relative to" a candidate, held that since this provision applied to fully protected speech it should be restricted "to expenditures for communications that in express terms advocate the election or defeat of a clearly identified candidate for federal office." Id. at 647 n.52. Similarly, in the context of advocacy of criminal acts the Court has adopted a test requiring express advocacy of imminent violence or lawlessness. See note 197 infra; Gunther, Learned Hand and the Origins of Modern First Amendment Doctrine: Some Fragments of History, 27 StAN. L. REv. 719, 728 (1975). 
posals. But an implied proposal test would be difficult to apply in a consistent and predictable manner. Courts would probably interpret a picture of a cigarette package against a pastoral setting or a television testimonial that "Brand X worked for me" as implied proposals of a transaction; however, the standards for making these judgments are unclear. When courts are called on to make more difficult judgments, such as determining whether a televised advertisement boasting of the productivity of a steel company constitutes an implied proposal to sell steel, the definition could lead to unjustifiably inconsistent results. The commercial proposal definition is thus caught in an unhappy dilemma: in one version it is underinclusive; in the other it is excessively vague. ${ }^{140}$

2. Speech of interest to a nondiverse consumer audience. A second formulation of the commercial speech definition is suggested by Bigelow v. Virginia. The Court spoke of the advertisement under consideration as "of potential interest and value to a diverse audience-not only to readers possibly in need of the services offered, but also to those with a general curiosity about, or genuine interest, in the subject matter." ${ }^{141}$ This passage suggests that the commercial speech concept should be restricted to speech of interest only to those individuals who form the potential market for the commodity or service advertised..$^{142}$ Although similar to the public interest test, this approach is narrower, and would avoid the ambiguities inherent in defining the public interest. ${ }^{143} \mathrm{~A}$ nondiverse audience test also appears to encompass more of the speech sharing the characteristic of lower value than the express proposal definition. Speech of interest only to actors in a particular economic marketplace includes both express proposals of a transaction and messages of more subtle persuasion.

Unfortunately, the nondiverse audience test is also underinclusive. An advertisement could attract a diverse following by virtue of publicity about its patent falseness, or about the illegality of the proposed transaction, rather than by virtue of the information or ideas presented. ${ }^{144}$ Under the nondiverse audience test, such adver-

140 See text following note 151 infra.

14 Bigelow v. Virginia, 421 U.S. 809, 822 (1975) (emphasis added).

$1+2$ For a case relying in part on a diverse audience test for commercial speech, see Wortham v. Dun \& Bradstreet, Inc., 399 F. Supp. 633, 639 n.2 (S.D. Tex. 1975).

${ }_{143}$ See note 133 supra. For an analysis of the closely related, and equally elusive, concept of newsworthiness, see Comment, The Right of Privacy: Normative-Descriptive Confusion in the Defense of Newsworthiness, 30 U. CHI. L. REv. 722 (1963).

is See 42 Tenn. L. Rev. 573, 581 (1975); cf. New Jersey State Lottery Comm'n v. United States, 491 F.2d 214, 222-23 (3d Cir. 1974) (rejecting the premise "that the size of the class 
tisements would be treated as noncommercial speech.

The test has other serious shortcomings. As Bigelow illustrates, ${ }^{145}$ it is not clear how a court is to ascertain whether an advertisement has a diverse appeal. Would survey data or expert testimony be admissible to show a diverse audience, or would the court rely on its own intuition? ${ }^{146}$ The nondiverse audience definition also seems vulnerable to the sham editorializing that the Court hoped to avoid by rejecting a "public interest" test for protected advertising; ${ }^{147}$ some form of primary purpose test would be required to prevent the test from becoming unenforceable. These administrative difficulties and the underinclusiveness of the test make another alternative preferable.

3. Speech about a brand name product or service. A third alternative defines commercial speech as speech about a brand name product or service ${ }^{148}$ - that is, speech about a commercial commodity identifying the seller of the commodity. ${ }^{149}$ This definition includes implied as well as express commercial proposals and covers all advertising that promotes particular products and services regardless of the public's interest. While avoiding the underinclusiveness of the two previous alternatives, however, the test may overinclusively reach speech that directly contributes to shaping public opinion. Under the test the commercial speech category

of persons interested determines what is news"), vacated for possible mootness, 420 U.S. 371 (1975).

${ }_{145}$ The Court found that the advertisement for a New York abortion referral agency was "not unnewsworthy." 421 U.S. at 822 . It is not clear whether the Court based this finding on its assessment of the content of the advertisement or on judicial notice of the public controversy surrounding the issue of abortion.

${ }_{1 \text { th }}$ See Rosenbloom v. Metromedia, Inc., 403 U.S. 29, 79 (1971) (Marshall, J., dissenting):

[A]ssuming that under the [public interest test] . . courts are not simply to take a poll to determine whether a substantial portion of the population is interested or concerned in a subject, courts will be required to somehow pass on the legitimacy of interest in a particular event or subject . . . . The danger such a doctrine portends for freedom of the press is apparent.

197 See text and note at note 134 supra.

${ }_{11 \times}$ For cases accepting, at least by implication, the brand name limitation, see Population Servs. Int'l v. Wilson, 398 F. Supp. 321, 337 (S.D.N.Y. 1975); Baird v. La Follette, 72 Wis.2d 1, 239 N.W.2d 536, 539 (1976); cf. Virginia State Bd. of Pharmacy v. Virginia Citizens Consumer Council, 96 S. Ct. 1817, 1835 (1976) (Stewart, J., concurring) (commercial advertising differs from ideological expression because it is limited to promoting specific goods and services).

${ }^{119}$ In the case of want ads the identification of a particular seller, even if only by a phone number or address, functions as a brand name. Want ads, therefore, would properly be considered commercial speech under the brand name definition. Cf. Pittsburgh Press Co. v. Pittsburgh Comm'n on Human Relations, 413 U.S. 376 (1973) (employment want ads are commercial speech); United States v. Hunter, 459 F.2d 205 (4th Cir.), cert. denied, 409 U.S. 934 (1972) (housing want ads are commercial speech). 
would include, for example, advertising that provides detailed factual information about the health or safety effects of a brand name product, or corporate advertising that rebuts the views of consumer or environmental groups concerning a specific commodity.

The brand name definition would create administrative difficulties not encountered in the other definitions examined. Some commercial advertising is sponsored by trade associations, and no brand name or particular seller is identified. ${ }^{150}$ The Supreme Court's understanding of the value of commercial advertising provides no basis for according advertising by a trade association greater value than advertising by a single seller. The identification of a particular trade association should therefore be interpreted as a collective brand name for a generic product or service. When this form of advertising concerns specific generic products or services, it should be treated as commercial speech. This step, however, still leaves courts with the problem of distinguishing between trade association advertising for specific types of generic goods, and trade association image advertising touting the virtues of the industry.

Administrative problems under the brand name definition also arise when the trade name of a particular corporation is synonymous with the brand name of a product or service sold by that corporation. If the mere use of such a corporate name is considered to be within the definition, corporations and businesses would engage in commercial speech whenever they used the company name, even in a political tract unrelated to the firm's business. In order to avoid giving sellers of commercial products indelible second-class speech rights, courts should consider the context in which the company name is used to determine whether it refers to the corporate entity or to a particular product. ${ }^{151}$

On the other hand, the brand name definition avoids some of the more troublesome problems of the alternative tests. Unlike the implied proposal version of the commercial proposal test, the brand

\footnotetext{
15i See National Comm'n on Egg Nutrition, FTC No. 8987 (July 20, 1976). A trade association of egg distributors' advertisements asserted that no competent or reliable scientific evidence demonstrates that eating eggs in quantity increases the risks of heart disease. The FTC found the advertisements deceptive and ruled that it had jurisdiction to prohibit their distribution since the sponsoring group had a direct financial interest in the sale of eggs and the advertising was intended to increase egg consumption. Id. at 3-7.

151 An editorial advertisement about energy policy signed by the "Exxon Corporation" would not be commercial speech if Exxon's products are not specifically mentioned, but a billboard carrying only the name "Exxon" should be construed to refer to a brand of gasoline and therefore to be commercial speech. Difficult borderline cases would likely arise, such as an Exxon advertisement that uses its own product to illustrate a discussion of the trend of gasoline prices.
} 
name test employs a single comprehensible standard: does the speech identify a particular seller or sellers of a specific type of commercial good? In contrast to the nondiverse audience test, it does not require the courts to ascertain the attitudes and interests of the general public. The problem of sham editorializing which attended previous tests should not undermine the brand name definition. Instances of "mixed" commercial and editorial advertising ${ }^{152}$ can be treated along the lines suggested by obscenity cases, in which the Court has considered a hypothetical pornographer who attaches "a quotation from Voltaire in the flyleaf" to invoke the protection of the first amendment. ${ }^{153}$ The Court has implied that if the unprotected material is not rationally related to the protected expression, the entire publication may be suppressed..$^{154}$ The speaker has the option of deleting the unprotected material and republishing the protected message with no loss in its meaning or nuance. ${ }^{155}$ Analogously, an advertisement that refers to a brand name product and contains editorial commentary should be treated as commercial speech if the editorial message could be republished without the brand name and lose no meaning or implication. ${ }^{156}$

${ }_{152}$ See Population Servs. Int'l v. Wilson, 398 F. Supp. 321, 337 (S.D.N.Y. 1975), prob. juris. noted, 96 S. Ct. 2621 (1976).

iss Kois v. Wisconsin, 408 U.S. 229, 231 (1972) (per curiam); see also Paris Adult Theatre I v. Slaton, 413 U.S. 49, 67 (1973).

${ }^{154}$ Kois v. Wisconsin, 408 U.S. 229, 230-31 (1972) (per curiam).

155 See Note, Community Standards, Class Actions, and Obscenity under Miller $v$. California, 88 Harv. L. REv. 1838, 1856 (1975).

${ }_{15 \mathrm{~A}}$ In most circumstances severing brand names from editorial advertising will not create serious difficulties. For regulation of false and deceptive advertising the severability principle means that representations about brand name products in an advertisement can be regulated as commercial speech, even if editorial or public interest statements are also present. However, a false statement of fact in the editorial portion unrelated to a brand name product would not trigger rigorous regulation of falsity, even if a brand name product is mentioned elsewhere in the advertisement. Similarly, few difficulties should arise when the advertisement as a whole must be classified as commercial or noncommercial for purposes of time, place and manner regulation-the problem in Chrestensen-or where commercial advertisements for certain products or services are forbidden altogether-the problem in Bigelow. Under the severability principle the advertisements considered in both Chrestensen and Bigelow would be commercial speech, since the "public interest" message in either case could be republished without the accompanying identification of a particular seller or services.

The primary inadequacy of the severability test occurs in cases where a brand name product or service is itself the subject of an editorial advertisement. In this narrow context courts should consider whether the reference to the brand name product is made to condition the market for the product or to contribute to the discussion of public issues. Cf. Watts v. United States, 394 U.S. 705, 708 (1969) (use of threatening language against the President of the United States found to be intended as political hyperbole). Thus, even under the severability test, a narrow area remains where scrutiny of the intention or purpose of the advertiser is necessary. 
In practice, the scope and operation of the three proposed definitions would not vary greatly. A typical corporate image advertisement ${ }^{157}$ that does not refer specifically to the corporation's goods or services would likely be held noncommercial speech under each alternative. Each of the proposed definitions is either underinclusive or overinclusive in terms of precisely reflecting the lower order of value the Supreme Court has discerned in commercial speech. Under the two-level theory of commercial speech the overinclusiveness of the brand name definition would make it unconstitutionally overbroad since it would permit government suppression of advertising with traditionally recognized first amendment value. ${ }^{158}$ After Virginia Board of Pharmacy, however, the function of a definition of commercial speech is not to separate fully protected from unprotected speech, but rather to distinguish fully protected speech from speech subject to governmental regulation under a less rigorous balancing test. ${ }^{159}$ An underinclusive definition would make it difficult, if not impossible, for the government to regulate certain types of commercial advertising; an overinclusive

157 Corporate image advertising has been defined as advertising that "describes the corporation itself, its activities or its policies, but does not explicitly describe any products or services sold by the corporation." FTC Staff, Statement of Enforcement Policy by the Federal Trade Commission Regarding Corporate Image Advertising 1-2 (Dec. 4, 1974). Obviously such advertising could not be considered connmercial speech under the brand name definition. See Bird, Goldman \& Lawrence, Corporate Image Advertising: A Discussion of the Factors That Distinguish Those Corporate Image Advertising Practices Protected Under the First Amendment from Those Subject to Control by the Federal Trade Commission, 51 J. UrBan L. 405 (1974). The authors suggest that "for corporate image advertising to be subject to control, the false, deceptive, misleading or unfair portion of the advertisement must have an appreciable effect on the market-place appeal of the advertiser's product or service." Id. at 418 . Their illustration of this principle indicates that it is substantially identical to the brand name definition.

Thus, a steel company could discuss the ills of drugs in deceptive terms, but it could not use deception in discussing its method of producing steel. A drug company could discuss its personnel policies without losing first amendment protection, provided it did not infer [sic] that those policies produced better drugs. A wood-products company could advertise the need for reforestation, but it could not escape control if it implied that its growing methods produced better lumber.

Id. at 418-19. For a contrary view, see Note, The Regulation of Corporate Image Advertising, 59 MinN. L. REv. 189, 200-01, 203-04 (1974) (rejecting the product-marketplace test as too inflexible and advocating case-by-case balancing).

${ }^{155}$ In obscenity and fighting words cases, which are still analyzed under the two-level theory, the Court has been repeatedly concerned to frame a narrow definition of nonprotected speech that does not encompass speech with first amendment value. See Miller v. California, 413 U.S. 15, 24 (1973); Memoirs v. Massachusetts, 383 U.S. 413, 418 (1966); Roth v. United States, 354 U.S. 476 (1957) (obscenity); Gooding v. Wilson, 405 U.S. 518, 524 (1972); Chaplinsky v. New Hampshire, 315 U.S. 568, 572 (1942) (fighting words). This concern has not carried over into the commercial speech context.

15. See text and notes at notes 99-104 supra. 
definition would provide some commercial advertising, which may contain a particularly valuable message, a lower degree of protection than that afforded a similar message uttered outside the commercial context. If the choice is between more effective vindication of the public interests served by advertising regulations and a marginal infringement on the first amendment rights of advertisers, the overinclusive definition seems preferable. The brand name definition, because of its ease of application, also seems the most workable.

\section{Further Limitations on the Definition of Commercial Speech}

The substantive inadequacies of all three definitional alternatives may be mitigated by other limits on the commercial speech definition that help assure that the reduction in first amendment protection afforded commercial advertising does not endanger important interests. First, the definition should apply only to speakers who have a financial interest either in the sale of the particular product or service being advertised or in the sale of a competing product or service. Media distributors of commercial advertising should be found to engage in commercial speech only if they have received compensation for disseminating the advertisement.

The financial interest limitation, which has been generally respected by the courts, ${ }^{160}$ reflects the judgment that the first amendment rights of authors, publishers, and broadcasters without such an interest should not be diminished when they speak on a commercial subject. ${ }^{161}$ The limit is supported by the fundamental first amendment policy of according publishers and broadcasters virtually absolute editorial discretion to choose subjects to speak

Int See New Jersey State Lottery Comm'n v. United States, 491 F.2d 214, 224 (3d Cir. 1974), remanded for possible mootness, 420 U.S. 371 (1975) (dictum); compare Perma-Maid Co. v. FTC, 121 F.2d 282 (6th Cir. 1941), with Scientific Mfg. Co. v. FTC, 124 F.2d 640, 644 (3d Cir. 1941) (virtually identical information about health effects of using aluminum cookware not subject to regulation as deceptive advertising when disseminated by publisher with no financial interest in competing product, but subject to regulation when disseminated by competing manufacturer). But see SEC v. Wall Street Transcript Corp., 422 F.2d 1371 (2d Cir.), cert. denied, 398 U.S. 958 (1970) (suggesting that the financial reports about securities in a newspaper for financial analysts were commercial speech); Bose Corp. v. Consumers Union of United States, Inc., 181 U.S.P.Q. 543 (D. Mass. 1974) (ruling that an allegation that a consumer magazine made false statements about a commercial product states a cause of action against the magazine under $\S 43(\mathrm{a})$ of the Lanham Act, 15 U.S.C. $\$ 1125$ a (1970)).

161 See Pittsburgh Press Co. v. Pittsburgh Comm'n on Human Relations, 413 U.S. 376 (1973); cf. Virginia State Bd. of Pharmacy v. Virginia Citizens Consumer Council, $96 \mathrm{~S}$. Ct. 1817,1825 (1976) ("No one would contend that our pharmacist may be prevented from being heard on the subject of whether, in general, pharmaceutical prices should be regulated, or their advertisement forbidden"). 
about. ${ }^{162}$ If publishers and broadcasters enjoyed only reduced first amendment protection for speech about brand name products, they could be deterred from engaging in robust discussion about controversial commercial activity. ${ }^{163}$ The limit also reflects a judgment that disinterested speech on commercial affairs will be more objective and sensitive to subjects of general public interest than speech by individuals with a financial stake in promoting a product. Finally, since individuals with such a financial interest are likely to resist the chilling effect of governmental regulation, ${ }^{164}$ their speech can be regulated more thoroughly than the speech of disinterested individuals without inducing silence.

Second, commercial speech should be defined to exclude advertising for activity that itself is protected by the first amendment. Advertisements for political, religious, or associational activities and for protected written works should be fully protected as an incident to the first amendment value of the underlying speech or activity. ${ }^{165}$ The additional value of such advertising does not depend on the presence of any ideas or information of public interest in the advertisement ${ }^{166}$ or on the absence of financial interest on the part of the advertiser, ${ }^{167}$ but derives from the constitutionally protected

${ }_{162}$ See Miami Herald Publishing Co. v. Tornillo, 418 U.S. 241, 256-57 (1974); Columbia Broadcasting Sys., Inc. v. Democratic Nat'l Comm., 412 U.S. 94, 126-27 (1973).

${ }^{163}$ For an example of robust discussion about brand name products, see R. NADER, Unsafe at ANy SpeEd (1972).

184 Virginia State Bd. of Pharmacy v. Virginia Citizens Consumer Council, 96 S. Ct. 1817, 1830 n.24 (1976).

${ }^{185}$ See, e.g., Buckley v. Valeo, 96 S. Ct. 612, 645 (1976) (limitation of personal expenditures for a candidate to an amount which would have prohibited placing a single, quarterpage advertisement in a major metropolitan newspaper held unconstitutional); New York Times Co. v. Sullivan, 376 U.S. 254 (1964) (advertisement soliciting funds for civil rights movement held noncommercial speech); Eastern R.R. Presidents Conference v. Noerr Motor Freight, Inc., 365 U.S. 127 (1961) (advertising campaign to influence legislature held exempt from antitrust laws); Thomas v. Collins, 323 U.S. 516 (1945) (solicitation of union membership treated as fully protected speech); Murdock v. Pennsylvania, 319 U.S. 105 (1943) (advertisement for religious book cannot be regulated as commercial speech). But compare Breard v. Alexandria, 341 U.S. 622 (1951) (upholding ordinance prohibiting door-to-door sales of periodicals), with id.at $650 \mathrm{n} .1$ (Black \& Douglas, JJ., dissenting) (finding ordinance unconstitutional as applied to solicitation of periodicals and distinguishing "merchant who goes from door to door selling pots"). See also Redish, The First Amendment in the Marketplace: Commercial Speech and the Values of Free Expression, 39 Geo. WASH. L. REv. 429, 432 (1971).

${ }_{166}$ Cf. Buckley v. Valeo, 96 S. Ct. 612, 648 (1976) ("Advocacy of the election or defeat of candidates . . . is no less entitled to protection under the First Amendment than the discussion of political policy generally . . ."); NAACP v. Button, 371 U.S. 415, 429 (1963) (first amendment protects vigorous advocacy as well as abstract discussion).

${ }_{167}$ See Virginia State Bd. of Pharmacy v. Virginia Citizens Consumer Council, $96 \mathrm{~S}$. Ct. 1817,1825 (1976) (speech is protected "even though it may involve a solicitation to purchase 
subject being promoted. ${ }^{168}$ To treat such advertising as commercial speech would inhibit the rights of publishers and authors to distribute their works and the rights of various organizations to recruit members, solicit funds, and publicize their ideas. ${ }^{169}$

Stated in full, the definition of commercial speech suggested by this comment is (1) speech that refers to a specific brand name product or service, (2) made by a speaker with a financial interest in the sale of the advertised product or service, in the sale of a competing product or service, or in the distribution of the speech, (3) that does not advertise an activity itself protected by the first amendment. This definition, though not without difficulties, should prove workable for courts applying the Supreme Court's ruling that commercial speech is not "wholly outside the protection of the First Amendment."'170

\section{The Standard of First Amendment Protection for COMMERCial SPEech}

In Bigelow $v$. Virginia, the Court formulated the standard for determining the constitutionality of commercial speech regulations as "assessing the First Amendment interest at stake and weighing it against the public interest allegedly served by the regulation."'171 Implicit in this standard is the view that different types of commercial speech have different first amendment value, and that the magnitude of governmental interest sufficient to justify an advertising regulation will vary according to the value of the advertising. ${ }^{172} \mathrm{Al}-$

or otherwise contribute money"); Bigelow v. Virginia, 421 U.S. 809, 818 (1975); Thomas v. Collins, 323 U.S. 516, 531 (1945).

18* Apparently advertising for activity protected by constitutional rights other than the first amendment can qualify as commercial speech. In Bigelow v. Virginia, 421 U.S. 809, 822 (1975), the Court implied that the fact the abortion advertisement pertained to "constitutional interests" enhanced its first amendment value. However, the Court accorded the advertisement no greater protection than the "purely commercial" advertising in Virginia State Bd. of Pharmacy v. Virginia Citizens Consumer Council, 96 S. Ct. 1817 (1976), or in Pittsburgh Press Co. v. Pittsburgh Comm'n on Human Relations, 413 U.S. 376 (1973). See text and notes at notes 88-97 supra. Thus the constitutional right to privacy, in which the right to have an abortion is grounded, does not place advertising for abortion services outside the scope of the commercial speech doctrine. See Population Servs. Int'l v. Wilson, 398 F. Supp. 321, 337 n.24 (S.D.N.Y. 1975), prob. juris. noted, 96 S. Ct. 2621 (1976).

1ay For cases recognizing the constitutional right to associate for the advancement of beliefs, see, e.g., Buckley v. Valeo, 96 S. Ct. 612, 636-37 (1976); NAACP v. Alabama ex, rel. Patterson, 357 U.S. 449 (1958).

170 Virginia State Bd. of Pharmacy v. Virginia Citizens Consumer Council, 96 S. Ct. 1817, 1825 (1976); id. at 1833 (Stewart, J., concurring).

171421 U.S. at 826 (1975).

172 Id. The Court stated: 
though Bigelow is not entirely consistent in stating a general standard for review, ${ }^{173}$ the Court in Virginia Board of Pharmacy adopted the balancing approach; it carefully articulated the first amendment value of the advertising under consideration and scrutinized the governmental interests asserted in support of the regulation. The Court also took the first steps toward identifying the different degrees of governmental interest required to sustain regulation in particular commercial speech contexts, ${ }^{174}$ and isolated a number of variables that may justify more rigorous regulation of some types of commercial speech. ${ }^{175}$ Rather than attempting a comprehensive survey of the ingredients that should be balanced in assessing the validity of regulations of commercial speech, this comment will examine four recurring types of controls to illustrate the operation of the balancing approach: regulation of false or deceptive advertising; time, place, and manner regulation of advertising with specific con-

The diverse motives, means, and messages of advertising may make speech "commercial" in widely varying degrees. We need not decide here the extent to which constitutional protection is afforded commercial advertising under all circumstances and in the face of all kinds of regulation.

${ }^{173}$ At one point the Court stated that "advertising, like all public expression, may be subject to reasonable regulation that serves a legitimate public interest." 421 U.S. at 826 ; see id. at $825 \mathrm{n} .10$. Insofar as this statement applies to noncommercial speech, it contradicts the central tenet that expression related to issues of public importance or to the search for truth can be regulated only upon a showing of a significant or compelling government interest. See note 23 supra. The cases cited in Bigelow for this proposition all, with the exception of Pittsburgh Press, dealt with time, place, and manner regulations of noncommercial speech. 421 U.S. at 826 \& n.11 (1975), citing Lehman v. City of Shaker Heights, 418 U.S. 298 (1974); Adderly v. Florida, 385 U.S. 39, 46-48 (1966); Cox v. Louisiana, 379 U.S. 536, 554 (1965); Poulos v. New Hampshire, 345 U.S. 395, 405 (1953); Kunz v. New York, 340 U.S. 290, 293-94 (1951); Cox v. New Hampshire, 312 U.S. 569, 575-76 (1941). Thus, the "reasonable regulation that serves a legitimate public interest" may have been intended to refer only to contentneutral time, place, and manner regulation. See The Supreme Court, 1974 Term, 89 Harv. L. REv. 47, 120 n.56 (1975). Even under this interpretation, the Court misstated the recognized standard, which requires the furtherance of "significant" or "important" not merely "legitimate" government interests. See, e.g., Erznoznik v. City of Jacksonville, 422 U.S. 205, 217 (1975); Grayned v. City of Rockford, 408 U.S. 104, 115 (1972).

Other language in Bigelow implies that the value of commercial speech and the weight of government interests should be assessed entirely on a case-by-case basis. 421 U.S. at 826; see 61 CORNELL L. Rev. 640, 653 (1976). While consistent with the overall balancing standard, this approach precludes the development of the generalized guidelines necessary if advertisers, media, and consumers are to be apprised of their constitutional rights, and if courts are to reach consistent resolutions of competing interests. See Gertz v. Robert Welch, Inc., 418 U.S. 323, 343-44 (1974). See also Gunther, In Search of Judicial Quality on a Changing Court: The Case of Justice Powell, 24 Stan. L. Rev. 1001, 1026 (1972); Frantz, The First Amendment in the Balance, 71 Y ALE L.J. 1424 (1962).

$17496 \mathrm{~S}$. Ct. at $1830-31$.

${ }^{175}$ Id. at $1830 \mathrm{n} .24 ;$ id. at $1833-35$ (Stewart, J., concurring); see text and notes at notes 114-19 supra. 
tent; prohibitions of advertising with specific content; and regulation of the media as distributors of advertising.

\section{A. Regulation of False or Deceptive Advertising}

The Court in Virginia Board of Pharmacy recognized that "untruthful speech, commercial or otherwise, has never been protected for its own sake." 176 Because untruthful speech generally has little or no first amendment value, false commercial speech may be regulated without requiring a demonstration in each case that legitimate public interests justify the regulation. ${ }^{177}$ The Court also noted several contextual factors that justify regulating factually erroneous commercial speech more rigorously than false statements of fact outside the commercial context. Because businesses have strong financial incentives to advertise, superior access to the facts about their products and services, and are not subject to severe time pressures in preparing advertisements, and because factual disputes about commercial products can be objectively resolved, commercial speech is more durable in the face of governmental regulation than noncommercial speech. ${ }^{178}$

The Court suggested that the low value of false commercial speech and the durability of commercial advertising permit the government to regulate commercial speech that is not demonstrably false, but only deceptive or misleading. ${ }^{179}$ In fact, in a footnote, the Court went so far as to suggest that some forms of commercial

$17696 \mathrm{~S}$. Ct. at 1830; see Gertz v. Robert Welch, Inc., 418 U.S. 323, 339 (1974) ("there is no constitutional value in false statements of fact"). But see Virginia State Bd. of Pharmacy v. Virginia Citizens Consumer Council, 96 S. Ct. 1817, 1834 (1976) (Stewart, J., concurring) ("disregard of the 'truth' may be employed to give force to the underlying idea expressed by the speaker"); New York Times Co. v. Sullivan, 376 U.S. 254, 279 n.19 (1964); Cantwell v. Connecticut, 310 U.S. 296, 310 (1940).

177 See 96 S. Ct. at 1830. The Federal Trade Commission has interpreted Virginia Board of Pharmacy not to require a case-by-case examination of the sufficiency of the governmental interest in the control of false and deceptive advertising. In National Comm'n on Egg Nutrition, FTC No. 8987 (July 20, 1976), the FTC stated:

We doubt that the Bigelow case compels the application of a balancing of interests test in each particular case before any regulation whatsoever may be applied to misleading commercial speech. That balance has already been struck on a categorical basis, a fact recognized by the Supreme Court in Virginia Board of Pharmacy if not in Bigelow itself.

Id. at 32. For earlier cases holding fraudulent or deceptive advertising unprotected, see, e.g., Donaldson v. Read Magazine, Inc., 333 U.S. 178 (1948); E.F. Drew \& Co. v. FTC, 235 F.2d 735, 740 (2d Cir.), cert. denied, 352 U.S. 969 (1956).

${ }^{17 \pi}$ See text and notes at notes 114-19 supra.

17. Despite the Court's approval of more extensive control over the veracity of commercial speech, regulations of deceptive advertising should be narrowly tailored to cure the deception with minimal interference to the advertising copy. See Beneficial Corp. v. FTC, 542 F.2d 611 (3d Cir. 1976). Further, the Court should not be interpreted as sanctioning the governmental 
advertising-such as advertising for medical or legal servicesmight be considered "inherently deceptive" given the nature of the services involved. 180

The Court also noted that false or deceptive commercial speech can be regulated by methods that would not be tolerated outside the commercial context. The Court implicitly approved requirements of affirmative disclosures in advertising and the use of prior restraints such as cease and desist orders to enforce administrative determinations of advertising deception. ${ }^{181}$ Presumably the requirement of a reviewable hearing before such an order is issued, mandated by the Court in other contexts involving injunctions or administrative licenses, such as obscenity regulation, also applies to the administrative regulation of false or deceptive commercial speech. ${ }^{182}$

The lower value of commercial speech and the durability of business advertising also lessen the need for prophylactic rules-such as a mens rea requirement-protecting untruthful commercial speech in order to ensure the free flow of truthful commer-

regulation of statements of opinion on public issues, no matter how erroneous they appear to the regulators. See National Comm'n on Egg Nutrition, or FTC No. 8987, at 34 (July 20, 1976).

1\$8 $96 \mathrm{~S}$. Ct. at $1831 \mathrm{n} .25$; see id. at 1831-32 (Burger, C.J., concurring). The Court gave little credence to the arguments that price advertising by pharmacists would drive scrupulous practitioners out of business and damage the image of the profession. Id. at 1828-29. Both arguments-in addition to concern about deception of the public-have been frequently put forward as justifications for prohibiting advertising by other professional groups. See Semler v. Oregon State Bd. of Dental Examiners, 294 U.S.608, 612 (1935); Note, Advertising, Solicitation and the Profession's Duty to Make Legal Counsel Available, 81 YaLE L.J. 1181, 118791 (1972). This term the Court has the opportunity to clarify whether the only permissible justification for the regulation of advertising by lawyers is the interest in preventing public deception. Bates v. State Bar of Arizona, 555 P.2d 640 (Ariz.), prob. juris. noted, $97 \mathrm{~S}$. Ct. 53 (1976). If the only constitutionally sufficient interest in regulating advertising by professionals is the prevention of public deception, state-enforced rules prohibiting all legal or medical advertising are clearly overbroad, since it is not difficult to think of some advertising by professionals-such as the identification of a practitioner and his field of specialization-that would not be deceptive in any way.

$18196 \mathrm{~S}$. Ct. at 1830 n.24; see Pittsburgh Press Co. v. Pittsburgh Comm'n on Human Relations, 413 U.S. 376, 390 (1973) (ruling that narrow injunction of repetitive course of commercial advertising did not constitute an impermissible prior restraint).

${ }_{1 \times 2}$ See, e.g., Blount v. Rizzi, 400 U.S. 410 (1971); Freedman v. Maryland, 380 U.S. 51 (1965); Monaghan, First Amendment "Due Process," 83 Harv. L. Rev. 518 (1970). Outside the commercial context the use of injunctions or schemes requiring regulatory approval of speech would constitute a constitutionally impermissible prior restraint. See, e.g., Nebraska Press Ass'n v. Stuart, 96 S. Ct. 2791 (1976); New York Times Co. v. United States, 403 U.S. 713 (1971); Near v. Minnesota, 283 U.S. 697 (1931). It has been suggested that the rationale for excepting commercial speech from the prohibition against prior restraints is the exceptionally low value of commercial advertising. See The Supreme Court, 1972 Term, 87 Harv. L. REv. 55, 158-60 (1973). The resistance of this type of speech to the chilling effect of governmental regulation, however, is an equally relevant factor. 
cial speech. ${ }^{183}$ The Court did not consider whether to condition the liability of business advertisers for false statements of fact upon a showing of fault as required by the libel cases. ${ }^{184}$ Since the mens rea requirement in the libel cases is grounded on the potential chilling effect that large damage awards against the media could have on vigorous reporting of true information of public interest, ${ }^{185}$ the mens rea requirement can be dispensed with in regulating false or deceptive speech by advertisers, at least in cases in which relief is limited to a cease and desist order. ${ }^{186}$

\section{B. Time, Place, and Manner Regulation of Advertising with a Specific Content}

Virginia Board of Pharmacy implies that greater governmental interests are required to support regulation of truthful commercial speech than to support regulation of false advertising. The Court also suggests that a time, place, and manner regulation of truthful advertising that "singles out speech of a particular content" for special treatment ${ }^{187}$ should be scrutinized more closely than a restriction not based on the content of the speech. The principle that content-specific regulations are more suspect than content-neutral regulations applies outside the commercial context as well. ${ }^{188}$

The Court's indication that content-specific regulations of commercial speech are suspect should not be interpreted to mean that time, place, and manner regulations that distinguish generally between commercial and noncommercial speech are necessarily invalid. A better interpretation of the Court's language is that time, place, and manner regulations that discriminate between speech of approximately equal value should be carefully scrutinized. Under this interpretation, time, place, and manner discrimination among

${ }_{1 \times 3}$ Virginia State Bd. of Pharmacy v. Virginia Citizens Consumer Council, 96 S. Ct. 1817, 1839 n.24 (1976); id. at 1833 (Stewart, J., concurring). The chilling effect of regulation applied to business advertisers is especially minimal if the regulation consists only of a cease and desist order directed at future advertising, as has been the case with FTC regulation of deceptive advertising. See 15 U.S.C. \$ 45(b) (Supp. V 1975).

I*4 See Time, Inc. v. Firestone, 96 S. Ct. 958 (1976); Gertz v. Robert Welch, Inc., 418 U.S. 323 (1974).

1*s See New York Times Co. v. Sullivan, 376 U.S. 254 (1964).

${ }_{1 \times 3}$ A different result may be required, however, when the regulation applies to the media distributing the advertisements. See text and notes at notes 243-53 infra.

ixi $96 \mathrm{~S}$. Ct. at 1830.

${ }^{1 \times *}$ See, e.g., Erzonznik v. City of Jacksonville, 422 U.S. 205, 214-15 \& n.13 (1975); Police Dep't v. Mosley, 408 U.S. 92, 95-96 (1972). See generally Stone, Fora Americana: Speech in Public Places, 1974 Sup. Ct. Rev. 233; Note, The Public Forum: Minimum Access, Equal Access, and the First Amendment, 28 Stan. L. Rev. 117 (1975). 
equally truthful advertisements for different products would be constitutionally suspect; however, the different first amendment value of ideological speech and commercial speech may make the commercial speech definition an appropriate dividing line for different degrees of time, place, and manner regulation. This is consistent with Young $v$. American Mini Theatres, Inc., ${ }^{189}$ where the plurality upheld different zoning regulations for ordinary movie houses and theatres featuring "sexually explicit" films on the ground that the low first amendment value in adult films justifies different time, place, and manner regulations of the theaters where they are featured. ${ }^{190}$

Under this interpretation, prohibitions of all commercial advertising on billboards ${ }^{191}$ or of all door-to-door commercial solicitation ${ }^{192}$ should be sustained if the different treatment of commercial and noncommercial speech is supported by legitimate public interests. ${ }^{193}$ However, a prohibition of billboard advertising for one product or service, such as abortion clinics, when no other advertising is restricted by content, ${ }^{194}$ should be more strictly scrutinized, and perhaps sustained only if supported by significant governmental interests. ${ }^{195}$

\section{Prohibitions of Advertising for Specific Products and Services}

The constitutional problems raised by time, place, and manner regulations of speech with specific content are even more apparent when the government attempts to prohibit such speech altogether. The volume of constitutional litigation ${ }^{196}$ concerning prohibitions of

1*9 96 S. Ct. 2440 (1976).

190 Id. at 2452.

191 See Howard v. State Dep't of Highways, 478 F.2d 581 (10th Cir. 1973); Markham Advertising Co. v. State, 73 Wash. 2d 405, 439 P.2d 248, appeal dismissed, 393 U.S. 316 (1969).

${ }_{192}$ Breard v. City of Alexandria, 341 U.S. 622 (1951).

${ }^{193}$ See Bigelow v. Virginia, 421 U.S. 809, 819 (1975) (characterizing Valentine v. Chrestensen, 316 U.S. 52 (1942), as upholding a "reasonable regulation of the manner in which commercial advertising could be distributed").

194 See Mitchell Family Planning, Inc. v. City of Royal Oak, 335 F. Supp. 738 (E.D. Mich. 1972).

195 See Police Dep't v. Mosley, 408 U.S. 92, 98-99 (1972); Stone, supra note 188.

196 See, e.g., Bigelow v. Virginia, 421 U.S. 809 (1975) (advertisement for abortion referral agency); Population Servs. Int'l v. Wilson, 398 F. Supp. 321 (S.D.N.Y. 1975), prob. juris. noted, 96 S. Ct. 2621 (1976) (prohibition of abortion and contraceptive advertising); Pittsburgh Press Co. v. Pittsburgh Comm'n on Human Relations, 413 U.S. 376 (1973); United States v. Hunter, 459 F.2d 205 (4th Cir.), cert. denied, 409 U.S. 934 (1972) (prohibitions of discriminatory advertising); Hiett v. United States, 415 F.2d 664 (5th Cir. 1969), cert. denied, 397 U.S. 936 (1970) (prohibition of advertising means to procure divorce); New York State 
truthful advertising for specific products or services, and the seriousness with which content-specific speech regulation is viewed outside the commercial speech context, ${ }^{197}$ warrant a detailed examination of the appropriate standard of review for such prohibitions.

Prohibitions of truthful advertising for particular commodities and services are enacted in response to a quality of the commodity or activity advertised rather than of the speech itself. ${ }^{198}$ The promoted product may have an undesirable effect on the health or wellbeing of consumers, ${ }^{199}$ may endanger third parties, ${ }^{200}$ or may threaten community moral standards. ${ }^{201}$ The government's purpose in prohibiting truthful advertising for such commodities and services is to protect health, safety, and welfare by controlling public demand for the products. The standard for evaluating such prohibitions may depend on whether the government has expressed its interest in controlling demand by making the advertised transaction itself illegal.

Broadcasters Ass'n v. United States, 414 F.2d 990 (2d Cir. 1969), cert. denied, 396 U.S. 1061 (1970) (prohibition of lottery broadcasts); United States v. Trentman, 408 F. Supp. 994 (C.D. Cal. 1976) (prohibition of mailing pandering advertisements).

${ }_{197}$ Outside the commercial speech context the Court has erected a highly protective standard for determining when speech advocating undesirable activity may be punished.

[T] he constitutional guarantees of free speech and free press do not permit a State to forbid or proscribe advocacy of the use of force or of law violation except where such advocacy is directed to inciting or producing imminent lawless action and is likely to incite or produce such action.

Brandenburg v. Ohio, 395 U.S. 444, 447 (1969). A similarly protective standard applies even if the speech involved is not expressly political. See T. Emerson, The System of Freedom of EXPRESSION 404 (1970) (solicitation of a crime governed by incitement test); 1 NATIONAL Comm'n on Reform of Federal Criminal Laws, Working Papers 371 (1970) (proposed Federal Criminal Code solicitation of crime section drafted to conform to incitement standard); cf. Kingsley Int'l Pictures Corp. v. Regents of the University of New York, 360 U.S. 684, 688 (1959) (first amendment "protects advocacy of the opinion that adultery may sometimes be proper, no less than advocacy of socialism or the single tax"); Musser v. Utah, 333 U.S. 95, 101-03 (1948) (Rutledge, J., dissenting) (advocacy of polygamy cannot be punished if it falls short of specific incitement). The protective requirements of express incitement and imminent danger have not been imposed when the speech involved is commercial. See Pittsburgh Press Co. v. Pittsburgh Comm'n on Human Relations, 413 U.S. 376 (1973).

19* See generally Developments in the Law-Deceptive Advertising, 80 HaRv. L. REv. 1005, 1036 (1967); Note, Freedom of Expression in a Commercial Context, 78 HaRv. L. REv. 1191, 1195-98 (1965).

109 See, e.g., Capital Broadcasting Co. v. Mitchell, 333 F. Supp. 582, 584 (D.D.C. 1971) (dictum), aff'd, 405 U.S. 1000 (1972) (upholding ban on broadcasting of cigarette commercials).

200e, e.g., N. DAK. CENT. CODE $\$ 62-01-14$ (5) (1960) (prohibiting placard advertising by licensed retail pistol dealers).

201 See, e.g., New York State Broadcasters Ass'n v. United States, 414 F.2d 900 (2d Cir. 1969), cert. denied, 396 U.S. 1061 (1970) (sustaining prohibition of broadcasting of promotional lottery advertisements). 
1. Prohibitions of Advertising for Illegal Products and Services. In Pittsburgh Press, the Supreme Court sustained a prohibition of speech proposing an illegal transaction without subjecting the prohibition to scrutiny under a balancing test; the Court indicated, however, that such scrutiny would have been required had the prohibition applied to speech proposing a legal transaction. ${ }^{202}$ The distinction between promoting illegal and legal commercial transactions conforms to the traditional understanding of first amendment values. ${ }^{203}$ Ideological speech that incites the commission of an unlawful act does not enrich the debate on public issues that can lead to peaceful change, but only serves to induce illegal action. ${ }^{204}$ Similarly, commercial speech that proposes an illegal transaction does not inform or persuade individuals in their lawful exercise of economic options, but only promotes activity that is outside the sphere of legitimate consumer choice. Because such speech has very little first amendment value, it can be prohibited without a case-by-case inquiry into the sufficiency of the government's interests.

2. Prohibitions of Advertising for Legal Products and Services: Less Restrictive Alternatives. The Court has not spoken directly to the circumstances in which truthful advertising for a legal commodity or enterprise can constitutionally be suppressed. ${ }^{205}$ The

${ }^{202}$ Pittsburgh Press Co. v. Pittsburgh Comm'n on Human Relations, 413 U.S. 376, 38889 (1973). This ruling was reaffirmed in Bigelow v. Virginia, 421 U.S. 809, 821 (1975), and Virginia State Bd. of Pharmacy v. Virginia Citizens Consumer Council, 96 S. Ct. 1817, 1824 (1976).

${ }^{203}$ See Note, Freedom of Expression in a Commercial Context, 78 HaRv. L. Rev. 1191, 1196 (1965). For commentary critical of the Court's distinction between advertising for legal and illegal transactions, see De Vore \& Nelson, Commercial Speech and Paid Access to the Press, 26 Hastings L.J. 745, 761-63 (1975) ("government policy need only to be translated into a legal prohibition to justify restrictions on the press"); The Supreme Court, 1974 Term, 89 HARv. L. REv. 47, 118 (1975) (the difficulty of determining the exact nature of the activity being advertised could generate complex problems about whether prohibition of underlying activity is constitutional); 61 CoRnell L. REv. 640, $644 \mathrm{n} .15$ (1976) ("illegality has little to do with the public-interest aspect of the advertisement").

${ }^{204}$ See Masses Publishing Co. v. Patten, 244 F. 535, 540 (S.D.N.Y.) (L. Hand, J.) ("Words . . . which have no purport but to counsel the violation of law cannot by any latitude of interpretation be a part of that public opinion which is the final source of government in a democratic state") rev'd, 246 F. 24 (2d Cir. 1917); cf. Brandenburg v. Ohio, 395 U.S. 444, 448 (1969); Bond v. Floyd, 385 U.S. 116 (1966) (direct incitement of crime may be punished); California Motor Transp. Co. v. Trucking Unlimited, 404 U.S. 508, 514 (1972); Giboney v. Empire Storage \& Ice Co., 336 U.S. 490, 498, 502 (1949) (speech used as integral part of unlawful scheme may be punished). Vigorous advocacy of lawful objectives is protected by the first amendment. See, e.g., NAACP v. Button, 371 U.S. 415, 429 (1963); Thomas v. Collins, 323 U.S. 516, 534-36 (1945); Thornhill v. Alabama, 310 U.S. 88, 104-05 (1939).

${ }^{20.5}$ Although the Court has not expressly taken a position on the constitutionality of 
first amendment value of truthful advertising for legal products and services and the traditional suspicion of regulations that single out speech with a particular content for special treatment indicate that courts should scrutinize prohibitions of truthful advertising for particular lawful products or services more carefully than other types of advertising regulations. A more demanding standard than balancing advertising regulations against legitimate governmental interests is required. ${ }^{206}$

In Virginia Board of Pharmacy, the Court forcefully recognized a parallel between advocacy of legal activity in the political world and in the realm of production and consumption. ${ }^{207}$ The Court found that all the reasons advanced to support the prohibition of drug price advertising rested on protecting citizens by keeping them ignorant "of the entirely lawful terms that competing pharmacists are offering." ${ }^{208}$ Justice Blackmun noted:

There is, of course, an alternative to this highly paternalistic approach. That alternative is to assume that this information is not in itself harmful, that people will perceive their own best interests if only they are well enough informed, and that the

forbidding truthful advertising for lawful products, arguably a shift in the Court's attitude regarding the proper level of scrutiny for such regulation occurred between Bigelow and Virginia Board of Pharmacy. In Bigelow, the Court twice implied that to permit the prohibition of advertising the advertised commercial activity need only be "subject to regulation," a status considerably broader than illegality. 421 U.S. at $825 \mathrm{n} .10,826$. In addition, the fact that the advertised abortion services were legal was treated as just one factor to be weighed in the overall balancing. $I d$. at 822 . The impression created is that a similar standard of protection applies whether the advertised activity is legal or not. In Virginia Board of Pharmacy, however, the Court expressly sanctioned the prohibition of truthful advertising only where the proposed transaction is "illegal in any way." $96 \mathrm{~S}$. Ct. at 1831 . Justice Rehnquist's dissent interpreted this unqualified language as forbidding the regulation of "active promotion of prescription drugs, liquor, cigarettes and other products the use of which it has previously been thought desirable to discourage . . . so long as it is not misleading or does not promote an illegal product or enterprise." $96 \mathrm{~S}$. Ct. at 1835 . Although this is probably an exaggerated reading of the majority's holding, the fact that the Court expressed approval only of prohibitions of truthful advertising for illegal enterprises may indicate that prohibitions of advertising for legal activity will be scrutinized more strictly in the future.

${ }^{201}$ For commentary suggesting that Bigelow erred in not adopting a significant or compelling governmental interest standard for assessing commercial speech regulations, see The Supreme Court, 1974 Term, 89 Harv. L. Rev. 47, 120-21 \& n.60 (1975); 61 Cornell L. Rev. $640,650-53$ (1976). This criticism ignores the fact that not all commercial speech has equivalent value. The government should be allowed to regulate commercial speech of especially low value, such as false advertising or advertising promoting illegal activity, more rigorously in order to protect the legitimate nonspeech interests that commercial advertising may threaten; but when commercial speech has greater value this higher level of scrutiny is appropriate.

${ }^{217} 96 \mathrm{~S}$. Ct. at $1829-30$.

${ }^{211 \times}$ Id. at 1830. 
best means to that end is to open the channels of communication rather than to close them. ${ }^{209}$

The Court found that the first amendment had settled the choice between these alternatives in favor of free communication. ${ }^{210} \mathrm{Com}$ mercial advertising that informs consumers about "entirely lawful" options has a first amendment value not shared by commercial advertising for illegal products.

Distaste for governmental interests grounded in paternalism is also apparent in Bigelow, where the Court observed that "Virginia is really asserting an interest in regulating what Virginians may hear or read about [lawful] New York services."211 The Court suggested that the state could have availed itself of a less restrictive alternative by disseminating information to enable women in Virginia who were considering a New York abortion "to make better informed decisions when they leave." ${ }^{212}$ When an advertised commercial transaction is legal, the state should try to influence the choice of citizens whether to engage in the transaction by methods less restrictive than the suppression of all advertising. ${ }^{213}$

In three recent decisions involving the prohibition of truthful advertising for lawful commodities, judicial consideration of less restrictive alternatives would have enriched the balancing process and might have led to a different result. In Capital Broadcasting Co.

209 Id. at 1829.

210 Id. But cf. Paris Adult Theatre I v. Slaton, 413 U.S. 49, 64 (1973) (dictum) (state "blue sky" laws that regulate what sellers of securities may publish about their offerings are to "protect the weak, the uninformed, the unsuspecting, and the gullible from the exercise of their own volition").

211421 U.S. at 827.

${ }^{212}$ Id. at 824.

${ }^{213}$ For other commercial speech cases supporting a less restrictive alternatives analysis, see Beneficial Corp. v. FTC, 542 F.2d 611 (3d Cir. 1976); Linmark Assocs., Inc. v. Township of Willingboro, 535 F.2d 786, 797 (3d Cir. 1976), cert. granted, 45 U.S.L.W. 3340 (U.S. Nov. 9, 1976); United States v. Pelligrino, 467 F.2d 41, 45 (9th Cir. 1972); Anderson, Clayton \& Co. v. Washington State Dep't of Agriculture, 402 F. Supp. 1253, 1257-58 (W.D. Wash. 1975); Fur Information \& Fashion Council, Inc. v. E.F. Timme \& Son, Inc., 364 F. Supp. 16, 22 (S.D.N.Y. 1973), aff'd, 501 F.2d 1048 (2d Cir.), cert. denied, 419 U.S. 1022 (1974). See generally Procunier v. Martinez, 416 U.S. 396, 413-14 (1974); Sheldon v. Tucker, 364 U.S. 479, 488 (1960); Martin v. City of Struthers, 319 U.S. 141, 148 (1943); The Supreme Court, 1974 Term, 89 HaRv. L. Rev. 47, 121 \& n.62 (1975).

Less restrictive alternatives analysis does not require that the government adopt only those alternatives that entail no loss of effectiveness or added costs. Rather it requires that the potential gain in free speech from using less restrictive regulatory methods be weighed against the loss in effectiveness or added costs of these alternatives. Thus, less restrictive alternatives analysis involves balancing "at the margin." Ely, Flag Desecration: A Case Study in the Roles of Categorization and Balancing in First Amendment Analysis, 88 HaRv. L. REv. 1482, 1484-85 \& n.16 (1975); Note, Less Drastic Means and the First Amendment, 78 YALE L.J. 464 (1969). 
v. Mitchell, ${ }^{214}$ a three-judge district court sustained a congressional prohibition of cigarette advertising on all broadcast media licensed by the federal government; ${ }^{215}$ the Supreme Court affirmed without an opinion. ${ }^{216}$ The district court found that commercial advertising is "less vigorously protected than other forms of speech" and had no difficulty sustaining the statute since in its view Congress had the power to prohibit the advertising of cigarettes in any media. ${ }^{217}$ Although the substantial public health danger from smoking justifies at least some governmental regulation of cigarette advertising, cigarette consumption is a lawful activity about which consumers should be entitled to receive truthful information. Advertising regulations to control demand for cigarettes that are less restrictive than complete suppression include governmentally supplied or enforced "counter speech" 218 such as the warnings concerning the health hazards created by cigarette smoking that are now required on cigarette advertising outside the electronic media. ${ }^{219}$ A court faced with a total prohibition of cigarette advertising should consider whether these less restrictive alternatives adequately serve the governmental interests in controlling public demand for cigarettes. If so, the complete prohibition should be overturned as unconstitutional.

A prohibition of cigarette advertising applicable only to the electronic media is less onerous than a prohibition covering all media. Cigarette manufacturers and consumers have access to forums other than radio and television for communicating and receiving commercial information about cigarettes. ${ }^{220}$ However, requiring cigarette advertising outside the electronic media only to carry a health warning while prohibiting cigarette advertising on

${ }^{214} 333$ F. Supp. 582 (D.D.C. 1971), aff'd, 405 U.S. 1000 (1972).

21515 U.S.C. $\$ 1335$ (1970). The relevant portion reads:

Sec. 6. After January 1, 1971, it shall be unlawful to advertise cigarettes on any medium of electronic communication subject to the jurisdiction of the Federal Communications Commission.

218405 U.S. 1000 (1972).

${ }^{217} 333$ F. Supp. at 584.

${ }^{218}$ See Bigelow v. Virginia, 421 U.S. 809, 824 (1975); cf. Whitney v. California, 274 U.S. 357, 379 (1927) (Brandeis, J., concurring) ("If there be time to expose through discussion the falsehood and fallacies . . . the remedy to be applied is more speech, not enforced silence").

219 Matter of Lorillard, 80 FTC 455 (1972) (consent order); see 15 U.S.C. § 1336 (1970) (requiring health warning on cigarette packages).

${ }^{220}$ The Court has often stated that "one is not to have the exercise of his liberty of expression in appropriate places abridged on the plea that it may be exercised in some other place." Schneider v. State, 308 U.S. 147, 163 (1939); see, e.g., Southeastern Promotions, Ltd. v. Conrad, 420 U.S. 546, 556 (1975). In Virginia Board of Pharmacy, however, the Court stated only that time, place and manner regulations must "leave open ample alternative channels for communication of this information." $96 \mathrm{~S}$. Ct. at 1830. 
the electronic media raises a first amendment-equal protection problem. ${ }^{221}$ Since the prohibited advertisements contain true information about a lawful product, the court should have required more than a showing of reasonable governmental interests, or the "unique characteristics of electronic communication,"222 to justify such disparate treatment. The most persuasive reason for regulating radio and television advertising more rigorously is that these forums create a captive audience. ${ }^{223}$ In particular, regulators fear that impressionable children will be exposed to advertising for a harmful product they otherwise would not be induced to consume. ${ }^{24}$ This problem might be overcome without a total prohibition by banning cigarette advertising from "family hour" viewing and allowing it at times when few children are likely to be watching. Although a court might ultimately reject this solution, since it is less effective than complete prohibition in the electronic media, the alternative should have been included in a meaningful balancing of the first amendment interests at stake. ${ }^{225}$

221 See Police Dep't v. Mosley, 408 U.S. 92, $94-98$ (1972). See generaily Karst, Equality as a Central Principle in the First Amendment, 43 U. CHI. L. Rev. 20 (1975).

${ }_{222}$ Capital Broadcasting was distinguished on this basis in Virginia State Bd. of Pharmacy v. Virginia Citizens Consumer Council, 96 S. Ct. 1817, 1831 (1976); Bigelow v. Virginia, 421 U.S. 809, 825 n.10 (1975); Pittsburgh Press Co. v. Pittsburgh Comm'n on Human Relations, 413 U.S. 376, 387 (1973). For fuller exposition of the "unique characteristics" doctrine, see Red Lion Broadcasting Co. v. FCC, 395 U.S. 367 (1969); National Broadcasting Co. v. United States, 319 U.S. 190, 226-27 (1943).

${ }^{223}$ Columbia Broadcasting Sys., Inc. v. Democratic Nat'l Comm. 412 U.S. 94, 127 (1973) (noting that "in a very real sense listeners and viewers constitute a 'captive audience" "); Banzhaf v. FCC, 405 F.2d 10-82, 1101 (D.C. Cir. 1968), cert. denied, 396 U.S. 842 (1969). See generally Kozyris, Advertising Intrusion: Assault in the Sense, Trespass on the Mind-A Remedy Through Separation, 36 Oнго ST. L.J. 299 (1975). The Court has given little weight to the captive audience problem outside the broadcast context, at least when the affected viewers or listeners can take relatively costless measures to avoid the offensive speech. Compare Erznoznik v. City of Jacksonville, 422 U.S. 205, 208-12 (1975), and Cohen v. California, 403 U.S. 15 (1971), with Lehman v. City of Shaker Heights, 418 U.S. 298, 307-08 (1974) (Douglas, J., concurring). The captivity problem presented by broadcast advertising is different in that it pertains to subliminal persuasion rather than offensiveness. See Banzhaf v. FCC, 405 F.2d 1082, 1100-01 (D.C. Cir. 1968), cert. denied, 396 U.S. 842 (1969). Although this concern should not justify the total exclusion of advertising for legal products from television and radio, it may justify regulation of the time and manner of advertising particular products in order to minimize the impact on minors. See Note, The Limits of Broadcast SelfRegulation Under the First Amendment, 27 Stan. L. Rev. 1527, 1544-58 (1975).

${ }^{224}$ See Note, The Limits of Broadcast Self-Regulation Under the First Amendment, 27 Stan. L. Rev. 1527, 1544-58 (1975).

${ }_{225}$ A related problem is illustrated by a federal statute and regulations that prohibit the broadcasting of lottery advertisements. See 18 U.S.C. $\$ 1304$ (1970); 47 C.F.R. $\$ \S 73.122, .292$, .656 (1976); New York State Broadcasters Ass'n v. United States, 414 F.2d 990 (2d Cir. 1969), cert. denied, 396 U.S. 1061 (1970). See also New Jersey State Lottery Comm'n v. United States, 491 F.2d 219 (3d Cir. 1974), vacated and remanded, 420 U.S. 371 (1975). The statute prohibits the broadcasting of all lottery advertisements regardless of the legality of the lottery 
A second illustration of less restrictive alternatives is provided by the facts in United States $v$. Hunter. ${ }^{226}$ The Fourth Circuit upheld a provision of Title VIII of the Civil Rights Act of $1968^{227}$ prohibiting all discriminatory housing advertisements even though the Act exempted owner-occupied facilities with less than five rental units from the substantive antidiscrimination provisions of the statute. ${ }^{228}$ In upholding the total ban, the court found that discriminatory advertisements for exempt housing may lead members of minority groups to believe that the entire neighborhood surrounding the advertised housing is segregated. This belief could deter them from seeking any housing in the area, including housing covered by the Act. ${ }^{229}$ The court did not inquire whether the implication of neighborhood segregation could be dispelled without a total prohibition by a requirement that discriminatory advertisements for exempt housing explicitly disclose that the accommodations are exempt from the Act. ${ }^{230}$ This does not mean that the court was wrong in upholding the full prohibition of discriminatory advertising. Racial discrimination in renting by owners of housing exempt from Title VIII is actionable under section 1982 of the Civil Rights Act, ${ }^{231}$ pro-

under local law. See New York State Broadcasters Ass'n v. United States, 414 F.2d 990, 996 (2d Cir. 1969), cert. denied, 396 U.S. 1061 (1970). The sweeping prohibition is justified in part on the ground that the use of interstate broadcast facilities by the operators of lawful lotteries might result in extending these lotteries into states where they are prohibited. Id. at 996 . The federal role should be more carefully tailored to differing state policies, since it is left to the states to determine the legal status of lotteries. Under this less restrictive policy, the federal government could deny operators of illegal lotteries access to interstate communications facilities, see, e.g., 18 U.S.C. $\$ 1084$ (1970) (proscription of interstate transmission of wagering information applies only where gambling is illegal in state of origin or state of destination); S. 1, 94th Cong., 1st Sess. $\$ 1841$ (1975), while allowing operators of legal lotteries to advertise, provided they add a disclaimer that citizens of states where the lottery is illegal are not permitted to participate. See, e.g., GA. CodE ANN. § 26-2705.1 (Supp. 1975). This less restrictive regulation protects the interests of citizens where the lottery is legal, the state's interest where the lottery is illegal, and does not burden the interstate dissemination of newspapers and periodicals.

226459 F.2d 205 (4th Cir.), cert. denied, 409 U.S. 934 (1972).

22742 U.S.C. $\$ 3604$ (c) (1970). The statute reads:

It shall be unlawful to make, print, or publish, or cause to be made, printed or published, any notice, statement, or advertisement, with respect to the sale or rental of a dwelling that indicates any preference, limitation, or discrimination based on race, color, religion, or national origin, or an intention to make any such preference, limitation, or discrimination.

${ }^{228} 42$ U.S.C. \& 3603 (b) (1970).

229459 F.2d at 214.

${ }^{200}$ Cf. United States v. West Peachtree Tenth Corp., 437 F.2d 221, 229 (5th Cir. 1971) (model decree requiring that housing advertisements include a statement disclosing that "apartments are rented without regard to race, color, religion, or national origin").

${ }^{231} 42$ U.S.C. $\& 1982$ (1970). 
hibiting racial discrimination in the sale or rental of property. ${ }^{232}$ Hunter therefore may be valid within the rule of Pittsburgh Press that advertising for unlawful discrimination can constitutionally be prohibited. ${ }^{233}$ In ignoring this aspect of the issue, and relying on an alternative interest that did not justify a total prohibition on discriminatory advertising, the court's constitutional scrutiny was incomplete. ${ }^{234}$

The third case, Morgan v. City of Detroit, ${ }^{235}$ involved a first amendment challenge to a city ordinance making it illegal to "accost, solicit or invite another . . . to commit fornication or prostitution." ${ }^{236}$ The plaintiffs argued that since prostitution was not a crime in either the city of Detroit or the state of Michigan, and fornication was not criminal in Michigan, the ordinance prohibited "soliciting someone to perform an act which is itself not criminal.",237

${ }^{232}$ See Jones v. Alfred H. Mayer Co., 392 U.S. 409 (1968).

${ }^{233}$ Pittsburgh Press Co. v. Pittsburgh Comm'n on Human Relations, 413 U.S. 376, 388 89 (1973). The injunction considered in Pittsburgh Press, see id. at 380, was narrowly tailored to apply only to discriminatory advertising for nonexempt employment positions. Id. at 38889.

${ }^{234}$ The less restrictive alternatives analysis is similarly useful, but not dispositive, in assessing local ordinances that forbid the use of "For Sale," "Sold," and "Open" signs in front of residences in order to combat the practice of blockbusting. See Linmark Assocs., Inc. v. Township of Willingboro, 535 F.2d 786 (3d Cir. 1976), cert. granted, 45 U.S.L.W. 3340 (U.S. Nov. 9, 1976); Barrick Realty, Inc. v. City of Gary, 491 F.2d 161 (7th Cir. 1974). The evil addressed by these statutes is the panic selling of homes brought on by fear of a sudden change in the racial balance of the neighborhood. In Linmark, the court noted that the challenged ordinance was narrowly drafted to attack this evil, as there was no restriction on the use of signs on model homes or on the use of newspaper advertisements. $535 \mathrm{~F} .2 \mathrm{~d}$ at 800 , 802. Even if further less restrictive means are not available, see Note, Freedom of Expression in a Commercial Context, 78 HARv. L. Rev. 1191, 1196 (1965), the balance of interests in these cases may not justify this form of content regulation. The ordinance may illegitimately impede the efforts of minority group members to buy homes if alternative sources of information about houses for sale-newspaper ads, for instance-are unavailable to members of minority groups because the realtors who control most of this advertising prefer white customers to minority customers. Moreover, the justification for the ordinance is similar to the justification for prohibiting drug price advertising disapproved by the Court in Virginia Board of Pharmacy, in that the Township is arguing for "the advantages of [its citizens] being kept in ignorance." $96 \mathrm{~S}$. Ct. at 1829. Given the Court's suspicion of these paternalistic justifications, the balance of interests in the blockbusting context may weigh in favor of free speech.

${ }^{235} 389$ F. Supp. 922 (E.D. Mich. 1975).

${ }^{238}$ Ordinances of the City of Detroit $\$ 39-1-52$, cited in 389 F. Supp. at 926 . The accosting and soliciting section provides, in relevant part:

It shall be unlawful for any person to accost, solicit or invite another in any public place or in or from any building or vehicle by word, gesture or any other means to commit or afford an opportunity to commit fornication or prostitution or to do any other lewd immoral act. It shall be unlawful for any male person to engage or offer to engage the services of a female person for the purposes of prostitution, lewdness or assignation, by the payment in money or other forms of consideration.

${ }^{237} 389$ F. Supp. at 926. 
The court held that soliciting prostitution or fornication is commercial speech without socially redeeming value and could be prohibited under Valentine $v$. Chrestensen. ${ }^{238}$

Given that prostitution and fornication were legal, and assuming that the solicitations were nondeceptive, the court should have inquired whether the government's interest in preventing neighborhood deterioration, the spread of prostitution, and offensive accosting of uninterested persons could be served without totally prohibiting the speech. An ordinance prohibiting the solicitation of lawful sexual acts by lewd or offensive language ${ }^{239}$ would be one permissible alternative to a total ban as a means of controlling offensive accosting. ${ }^{240}$ The government could pursue its interests in preventing neighborhood blight and the spread of prostitution by regulating the time, place, and manner of soliciting for lawful sexual acts..$^{241}$ Such regulations could prohibit solicitation for sexual purposes on public streets and sidewalks, or by means of a loudspeaker, even though other commercial solicitation is not so limited. ${ }^{242}$ If the less restrictive alternatives analysis were seriously applied, an ordinance that would prohibit nonoffensive advertising in all forums for lawful sexual commerce would be unconstitutional.

${ }^{238}$ Id. at 927.

${ }^{239}$ The high level of tolerance for offensive language required by the first amendment outside the commercial context might make such a prohibition invalid. See, e.g., Erznoznik v. City of Jacksonville, 422 U.S. 205 (1975); Hess v. Indiana, 414 U.S. 105 (1973); Cohen v. California, 403 U.S. 15 (1971). When commercial speech is involved, however, there may be a greater willingness to uphold restrictions on offensive speech. See Note, The Limits of Broadcast Self-Regulation Under the First Amendment, 27 Stan. L. Rev. 1527, 1536 n.40 (1975). The possibility of greater regulation of offensive (or obscene) language in the commercial context was not mentioned in Virginia State Bd. of Pharmacy v. Virginia Citizens Consumer Council, 96 S. Ct. 1817 (1976), or Bigelow v. Virginia, 421 U.S. 809 (1975). However, other Supreme Court decisions suggest that commercial promotion of erotica may be entitled to less protection than is accorded to erotic literature itself. See Hamling v. United States, 418 U.S. 87 (1974) (affirming jury verdict finding advertisement for book obscene, but the book itself nonobscene); Ginzburg v. United States, 383 U.S. 463 (1966). One reason for permitting more rigorous regulation of offensiveness in commercial advertising is the greater durability of commercial speech. See text at note 178 supra.

${ }^{240}$ For other cases dealing with offensiveness in commercial advertising, see, e.g., Hodges v. Fitle, 332 F. Supp. 504 (D. Neb. 1971) ("topless" dancing to promote alcoholic beverages construed as unprotected commercial speech); State v. Cardwell, 539 P.2d 169 (Or. App. 1975) (statute prohibiting use of nudity or sex for advertising purposes unconstitutional despite commercial speech context).

${ }^{241}$ The Court has indicated that sexually explicit speech is subject to more rigorous time, place, and manner regulation than speech containing a "social, political, or philosophical message." Young v. American Mini Theaters, Inc., 96 S. Ct. 2440, 2452 (1976).

${ }^{242}$ This exception to the general rule forbidding selective exclusion from a public forum, see Police Dep't v. Mosely, 408 U.S. 92, 99 (1972), is justified because of the low value of offensive commercial speech. See text and notes at notes 187-95 supra. 
The less restrictive methods analysis does not resolve all the questions about prohibitions of truthful advertising for lawful products and services. The great advantage of the technique is that it requires courts to carefully consider the adequacy of the governmental interests asserted to justify such prohibitions.

\section{Regulations of Commercial Advertising as Applied to Media Distributors}

The Supreme Court's emphasis in Virginia Board of Pharmacy on the durability of commercial advertising is useful in considering regulations of commercial advertising applied to the media as the distributors of such advertising. The media are generally more vulnerable to the chilling effects of governmental regulation of advertising because they have less financial interest than advertisers in the distribution of any particular type of advertising ${ }^{243}$ and lack the advertisers' access to the facts about specific products and services. Because of the proportionally small revenue the media derive from any one line of advertising, they have little incentive to expend time and resources in screening potentially deceptive or illegal ads. Moreover, the potential loss to the media is quite large if they can be held responsible for the content of the advertising they distributeparticularly if they can be held liable for damages or can be made subject to an injunction barring the distribution of an entire publication or broadcast. ${ }^{244}$ To avoid potentially serious chilling effects, the media should not be subject to criminal penalties, damages, or injunctive relief for the dissemination of particular advertising absent a showing of at least negligence in distributing the offending advertisement. ${ }^{245}$

243 See text and notes at notes 115-16 supra.

${ }^{24}$ See Manual Enterprises, Inc. v. Day, 370 U.S. 478 (1962). In overturning an administrative determination that a magazine publisher had disseminated advertising providing information as to where obscene material could be obtained, Justice Harlan stated:

[T] he power of the Post Office to bar a magazine from the mails, if exercised without proof of the publisher's knowledge of the character of the advertisements included in the magazine, would as effectively "impose a severe limitation on the public's access to constitutionally protected matter," . . . as would a state obscenity statute which makes criminal the possession of obscene material without proof of scienter. Since publishers cannot practicably be expected to investigate each of their advertisers, and since the economic consequences of an order barring even a single issue of a periodical from the mails might entail heavy financial sacrifice, a magazine publisher might refrain from accepting advertisements from those whose own materials could conceivably be deemed objectionable by the Post Office Department.

Id. at 493 .

245. If the only remedy available against the media were a cease and desist order, the 
Superior access to the facts about an advertised product is important in determining the proper standard of protection for media distributors when disputes over these facts are involved in applying advertising regulations. ${ }^{246}$ Access to facts becomes crucial in applying regulations of false or deceptive advertising or prohibitions of advertising for a product defined in terms of a quantitative variable, such as all beverages containing more than a specified percentage of alcohol. When the applicability of advertising regulations turns on questions of fact about a product that cannot be answered by examining the advertisement itself, more than a demonstration of negligence is required. ${ }^{247}$ The media, if they have no actual knowledge of the inculpatory facts about a product, should not be held liable for disseminating the advertisement even though an independent investigation of the product would reveal that it falls within the terms of the regulation. ${ }^{248}$ To impose liability in this context on

chilling effect would be negligible and the media could be subjected to such an order without a demonstration of fault.

216 The Court has emphasized superior access to facts in varying the standard of protection of speech in the context of labor relations. See NLRB v. Gissel Packing Co., 395 U.S. $575,617-20$ (1969), where the Court rejected a vagueness challenge to a labor statute forbidding employers to use threats of "reprisal or force or promise of benefit" during union organization drives, noting "an employer, who has control over [the employer-employee] relationship and therefore knows it best, cannot be heard to complain that he is without an adequate guide for his behavior. . . At the least he can avoid coercive speech simply by avoiding conscious overstatements he has reason to believe will mislead his employees." Id. at 620 .

${ }^{247}$ See Yuhas v. Mudge, 129 N.J. Super. 207, 322 A.2d 824 (N.J. Super. Ct. App. Div. 1974) (magazine publisher held not liable for printing advertisement for fireworks that had injured plaintiffs who had purchased them in response to the advertisement). But cf. Blinick v. Long Island Daily Press Publishing Co., 67 Misc. 2d 254, 323 N.Y.S.2d 853 (N.Y. City Ct. 1971), appeal dismissed, 71 Misc. 2d 986, 337 N.Y.S.2d 859 (Sup. Ct. 1972). In this case a newspaper was held liable for printing the wrong telephone number in an advertisement that on its face encouraged obscene calls. The incorrect number was apparently given the newspaper by the advertiser, but the publisher failed to check the number by calling it-"the work of only a minute or so." Unusual procedural aspects make the case suspect. See generally Annot., 10 A.L.R.2d 686 (1950).

A publisher may have the duty to investigate the products it advertises if it endorses the products. See Hanberry v. Hearst Corp., 276 Cal. App. 2d 680, 81 Cal. Rptr. 519 (1969). See generally Annot., 39 A.L.R.3d 181 (1971).

${ }^{248}$ [N]o such legal duty rests upon [a publisher of advertisements] unless it undertakes to guarantee, warrant or endorse the product. To impose the suggested broad legal duty upon publishers of nationally circulated magazines, newspapers and other publications, would not only be impractical and unrealistic, but would have a staggering adverse effect on the commercial world and our economic system. For the law to permit such exposure to those in the publishing business who in good faith accept paid advertisements for a myriad of products would open the doors "to a liability in an indeterminate amount for an indeterminate time to an indeterminate class." Ultramares Corp. v. Touche, Niven \& Co., 255 N.Y. 170, 174 N.E. 441, 444 (Ct. App. 1931).

Yuhas v. Mudge, 129 N.J. Super. 207, 209-10, 322 A.2d 824, 825 (N.J. Super. Ct. App. Div. 1974). 
a showing of mere negligence could deter the media from distributing any advertising related to the product, thereby depriving the public of a valuable source of commercial information. ${ }^{249}$ The requirement of actual knowledge, which the Supreme Court has approved for prohibitions of media distribution of advertising for obscene material, ${ }^{250}$ should assure that the flow of legitimate commercial information is not impeded by regulations of media distribution of advertising. Actual knowledge should not be required, however, when the information available to the media from the face of the advertisement would indicate to a reasonable person that the advertisement violates a regulation. ${ }^{251}$ For example, when the advertising of "cigarettes" 252 or "contraceptives" ${ }^{253}$ is prohibited, the media will generally have access to all the information they need to keep within the clear bounds of the regulation.

\section{ConcLusion}

This comment has argued that after Bigelow and Virginia Board of Pharmacy, the constitutionality of regulations of commercial speech should be assessed in the manner first suggested in Pittsburgh Press. Under this approach, courts should determine whether the speech at issue is commercial speech, then apply either the balancing test associated with commercial speech or the standard of strict scrutiny employed in measuring speech regulations outside the commercial speech context. In making this inquiry, the courts should adopt a definition of commercial speech based upon

${ }^{249}$ Cf. Gertz v. Robert Welch, Inc., 418 U.S. 323, 348 (1974) (the Court reserved judgment on the question whether in future libel actions by private individuals a higher degree of fault, perhaps actual malice, would be required "if a State purported to condition civil liability on a factual misstatement whose content did not warn a reasonably prudent editor or broadcaster of its defamatory potential"); State v. Beacon Publishing Co., 141 Kan. 734, 738-39, 42 P.2d 960, 964 (1935) (the court, in upholding the constitutionality of the state "printer's ink" statute as applied to a publisher, emphasized that under the statute a publisher must knowingly print false advertisement in order to be liable).

${ }^{250}$ Manual Enterprises, Inc. v. Day, 370 U.S. 478, 491-95 (1962); see Hamling v. United States, 418 U.S. 87, 123 (1974); Ginsberg v. New York, 390 U.S. 629 (1968); Mishkin v. New York, 383 U.S. 502 (1966).

${ }_{251}$ See United States v. Hunter, 459 F.2d 205, 213 (4th Cir.), cert. denied, 409 U.S. 934 (1972):

[A] publisher can readily determine from the face of an advertisement whether it is intended to express a discriminatory preference. However the languge of the advertisement is couched, the purpose of an advertiser who wishes to publish an advertisement in violation of the Act is to communicate his intent to discriminate and a publisher can divine this intent as well as any of his readers.

${ }^{252}$ See 15 U.S.C. $\$ \S 1332,1335$ (1970).

${ }^{253}$ See N.Y. Educ. Law § 6811(8) (McKinney 1972). 
the reduced first amendment value that the Supreme Court has identified as characteristic of commercial advertising. The proposed definition reflects this lower order of value and the greater durability of commercial advertising: commercial speech is speech referring to a brand name product or service that is not itself protected by the first amendment, issued by a speaker with a financial interest in the sale of the product or service or in the distribution of the speech.

Where the speech involved is within the terms of this definition, courts should review regulations under a balancing test that requires the governmental interests supporting the regulation to outweigh the first amendment value of the speech. In applying this balancing test, courts should consider such factors as whether the speech involved is false or deceptive, whether the regulation singles out advertising with particular content for special treatment, whether the activity advertised is itself illegal, and whether the speaker's incentives to advertise and his access to information about the item advertised make his speech more resistant to the chilling effects of regulation.

This comment has suggested that a showing of significant governmental interests should be required to sustain total prohibitions of truthful advertising for lawful products and services. Valid community interests in controlling the consumption of undesirable commercial products will not be frustrated by this requirement. As the court of appeals observed in Chrestensen $v$. Valentine, ${ }^{254}$ even if complete suppression of advertising for a particular product is unwarranted, less restrictive methods of regulating commercial advertising may be available to vindicate the government's interests. The Supreme Court's ill-considered ruling in Chrestensen obscured this insight, but three decades later the Court has seen its wisdom.

Thomas W. Merrill

254 122 F.2d 511 (2d Cir. 1941), rev'd, 316 U.S. 52 (1942). The Second Circuit observed: Absolute prohibition of expression "in the marketplace" is illegal, not to be saved by any commercial taint attached to the expression; reasonable regulation of soliciting, not preventing freedom of expression, is permissible. And in the latter case, where the soliciting is for profit, steps to identify, even to license, the soliciter may be upheld to prevent fraud upon or inconvenience to the public. (Note that this distinction between forms of solicitation may be made clear, definite, and workable, since it has a commonsense purpose in mind and deals with regulation, not prohibition. . . .)

Id. at 515 . 